9

0

1

\title{
Regional-scale variability in the spread of grasslands in the late Miocene
}

\author{
Stephanie T. Chen ${ }^{1}$, Selena Y. Smith ${ }^{1,2}$, Nathan D. Sheldon ${ }^{1,}$, Caroline A.E. Strömberg ${ }^{3}$ \\ ${ }^{1}$ Department of Earth \& Environmental Sciences, University of Michigan, Ann Arbor, MI 48109 \\ USA \\ ${ }^{2}$ Museum of Paleontology, University of Michigan, Ann Arbor, MI 48109 USA \\ ${ }^{3}$ Department of Biology and Burke Museum, University of Washington \\ corresponding author: email, sysmith@umich.edu
}

22

4

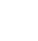




\section{Abstract}

27 A new paleovegetation reconstruction based on both phytolith and paleosol carbon isotopic data

28 is presented for the middle-late Miocene (11.2-9.5 Ma) of southwestern Montana. Both sources

29 of data indicate an open-habitat, $\mathrm{C}_{3}$ grassland ecosystem with a small $\mathrm{C}_{4}$ component $(<10 \%)$.

30 However, while a penecontemporaneous record from further south within the same region

31 indicated significant spatial and temporal variability in $\mathrm{C}_{4}$ abundance, the new record indicates

32 relatively little change either in space or in time. Because paleoclimatic conditions reconstructed

33 at these two sites are the same, we hypothesize that other ecological factors controlled $\mathrm{C}_{4}$

34 abundance across the region. The relative abundance of $\mathrm{C}_{3}$ and $\mathrm{C}_{4}$ plants in the Miocene is the

35 same as in modern environments at both sites, suggesting that their distribution was likely

36 established by the middle-late Miocene. This is consistent with the idea that paleoelevation was

37 also similar, which agrees with independent constraints on the regional tectonic history. The

38 Montana records indicate a more limited distribution of $\mathrm{C}_{4}$ vegetation than is observed in the

39 Great Plains and elsewhere globally, as well as variable timing in the shift to $\mathrm{C}_{4}$ dominance in

40 ecosystems. Taken together, this local, regional, and global variability during a time of little or

41 no climate change suggests that $\mathrm{C}_{4}$ distribution and expansion was driven by local, rather than

42 global, environmental factors.

44 Keywords: Montana; Neogene; paleoecology; paleosols; paleovegetation; phytoliths 


\section{Introduction}

Grass-dominated habitats today cover half of the Earth's land surface and are home to 1.8

47 billion people, providing key ecosystem services such as carbon burial and habitat, and are major range and croplands for agricultural production (Asner et al., 2004). The macrofossil record of

49 grasses is poor (e.g., Smith et al., 2010; Strömberg, 2002, 2011), but other lines of evidence

50 including functional morphology of large mammalian herbivores (e.g., Janis et al., 2000),

51 phytoliths (e.g., Strömberg, 2004, 2005), and stable isotope analyses of paleosols (e.g., Fox and

52 Koch, 2003) and mammal teeth (e.g., Cerling et al., 1997) have been used to examine the global

53 and regional evolutionary history of grasses. Of these, phytoliths and stable isotope analyses can

54 also be used to differentiate between photosynthetic pathways used by grasses (e.g., Fredlund

55 and Tieszen, 1997, McInerney et al., 2011).

56

$67 \mathrm{Ma}$ (Prasad et al., 2005). Following the first instance of evolution of $\mathrm{C}_{4}$ photosynthesis within

58 the tropical PACMAD clade of grasses, by at least the early Oligocene (Edwards et al., 2010, but see Urban et al., 2010), $\mathrm{C}_{4}$ grasslands spread globally at low-mid latitudes in the late Miocene to Pliocene (8 to $3 \mathrm{Ma}$ ) through the replacement of $\mathrm{C}_{3}$ vegetation (Cerling et al., 1997; Strömberg,

61 2011). The spread of $\mathrm{C}_{4}$ grasses was initially linked to low atmospheric $\mathrm{CO}_{2}$ levels (Cerling et al.,

62 1993), but subsequent work has found that a $\mathrm{CO}_{2}$-only trigger is unlikely (Pagani et al., 1999;

63 Bolton and Stoll, 2013; Zhang et al., 2013) and that additional local to regional scale drivers,

64 including changes in fire regime, aridity, and/or evolutionary niche tolerances, were likely to 65 have been important (Osborne, 2008; Edwards et al., 2010; Strömberg and McInerney, 2011). In 66 addition, different factors may have played a larger role in different regions (e.g., aridity and/or

67 rainfall seasonality in South Asia, Huang et al., 2007; Quade et al., 1989; temperature seasonality 

87 composition.

and/or aridity in the Great Plains, Fox et al., 2012; Strömberg and McInerney, 2011). Therefore, to understand the potential range of processes responsible for the spread of $\mathrm{C}_{4}$ grasslands, detailed region-specific studies are imperative.

The global expansion of $\mathrm{C}_{4}$ grasslands in the late Miocene has been well-documented at several sites (Edwards et al., 2010), but in many regions, $\mathrm{C}_{4}$ grasses were present for millions of years prior to becoming dominant and replaced $\mathrm{C}_{3}$ grasses rather than forest vegetation. For example, Miller et al. (2012) identified $\mathrm{C}_{3}$ grass phytoliths in Montana by $39 \mathrm{Ma}$ (at THA in

Fig. 1) but found no evidence of $\mathrm{C}_{4}$ vegetation based on either phytoliths or paleosol morphology. In contrast, Cotton et al. (2012) studied a nearby late Miocene site (TFF in Fig. 1; 10.2-8.9 Ma) and found patchy but measurable amounts (up to $25 \%$ ) of $\mathrm{C}_{4}$ vegetation based on organic carbon isotopic ratios from paleosol and phytolith evidence, as well as a different $\mathrm{C}_{3}$ grass phytolith assemblage than at the older site pointing to a shift in $\mathrm{C}_{3}$ species composition. Taken together, these sites bracket the local evolution or spread of $\mathrm{C}_{4}$ vegetation into southwestern Montana, and support previous ideas of a more complicated regional history for the spread of grasslands in general (Strömberg, 2005, 2011), and the presence of significant amounts of $\mathrm{C}_{4}$ plants prior to their global expansion to dominance in some regions (Fox and Koch, 2004; Edwards et al., 2010; Cotton et al., 2012). Here we present a new combined isotope geochemistry and phytolith record dated to $11.2-9.5 \mathrm{Ma}$ from the same region to fill in some of the gaps in the history of $\mathrm{C}_{4}$ grasses in the Rocky Mountain region and to examine local to regional scale variation in ecosystem

\section{Reconstructing Paleovegetation}

$\mathrm{C}_{3}$ and $\mathrm{C}_{4}$ photosynthesis fractionate ${ }^{12} \mathrm{C}$ and ${ }^{13} \mathrm{C}$ isotopes to different degrees, which forms the basis for calculating the vegetation contribution of each pathway towards the $\delta^{13} \mathrm{C}$ ratio 
91 of a soil or paleosol. Values for modern $C_{3}$ plants range from $-22 \%$ to $-34 \%$, with a mean of -

$9227 \%$, whereas values for $\mathrm{C}_{4}$ plants range from $-9 \%$ to $-16 \%$, with a mean of $-13 \%$ (Cerling and

93 Harris, 1999). These differences can be used to derive a two-member mixing model, with mean

$94 \delta^{13} \mathrm{C}$ values as pure $\mathrm{C}_{3}$ and $\mathrm{C}_{4}$ end members to calculate the percentage of $\mathrm{C}_{3}$ and $\mathrm{C}_{4}$ vegetation

95 abundance. Soil organic matter from A horizons record plant values quantitatively, with

96 significant enrichment in ${ }^{13} \mathrm{C}$ from oxidation occurring deeper in the profile in $\mathrm{B}$ and $\mathrm{C}$ horizons

97 (Garten et al., 2000; Wynn, 2007; Wynn and Bird, 2007) and as a function of grain size changes

98 (Wynn et al., 2005), but with minimal diagenetic alteration (Sheldon and Tabor, 2009). For

99 example, fine-textured soils may exhibit $\delta^{13} \mathrm{C}_{\text {org }}$ values at depth up to $+5 \%$ relative to their $\mathrm{A}$

100 horizons or overlying vegetation, whereas coarser-grained soils often exhibit less than $+1.5 \%$ at

101 depth relative to their A horizons (Wynn et al., 2005; Wynn, 2007). Thus, paleosol A horizon

$102 \delta^{13} \mathrm{C}_{\text {org }}$ values can be used to reconstruct past relative abundance of $\mathrm{C}_{4}$ vegetation most

103 accurately, with the upper parts of B horizons of sandy-textured soils also recording the relative

104 abundance of $\mathrm{C}_{4}$ vegetation fairly accurately; deeper profile depths or finer-grained soils

105 generally require some adjustment to measured value to be useful. The isotopic composition

106 range within a photosynthetic pathway has been linked to moisture availability and ecology

107 (Diefendorf et al., 2010; Kohn, 2010), with the highest $\mathrm{C}_{3}$ plant isotope values associated with

108 water-stressed regions (typically $+1-3 \%$ for the same plant relative to wetter climates; e.g.,

109 Cotton, 2013) and the lowest $\mathrm{C}_{3}$ plant isotope values associated with closed canopy settings.

110 Thus, whereas modern $\delta^{13} \mathrm{C}$ values much lower than $-25 \%$ in soil A horizons would likely record

111 closed canopy forest vegetation, values near $-25 \%$ could be reflecting a small proportion of $\mathrm{C}_{4}$

112 photosynthesis or water-stressed $\mathrm{C}_{3}$ vegetation. 
Phytoliths are microscopic plant silica bodies, produced by the deposition of monosilicic

114

115

116

117

118

119

120

121

122

123

124

125 Materials and Methods

126

127

128

129

130

131

132

133

134

135

\section{Field Site}

acid $\left(\mathrm{H}_{4} \mathrm{SiO}_{4}\right)$ between and within plant cells, which may take on the shape of its originating cell or other characteristic morphology (Piperno, 2006). As a result, phytolith morphology can often be used to identify the original plant taxon or habitat it was produced in, providing a means for vegetation reconstructions in deep time (e.g., Strömberg, 2004, 2005; Miller et al., 2012). Studies of phytolith production in modern plants and soils have helped identify characteristic morphotypes distinctive of plant taxa and functional groups (e.g., Piperno, 1985; Strömberg, 2003; Prychid et al., 2004; Chen and Smith, 2013), which can then be used in the identification of fossil phytoliths. However, representational biases may exist when considering relative abundance preserved in soils in certain environments (e.g., Fredlund and Tieszen, 1994; Barboni et al., 2007; Hyland et al., 2013) and should be accounted for in paleovegetation reconstructions.

Sampling took place at the Madison Buffalo Jump (MBJ) locality in southwestern Montana, which preserves part of the Sixmile Creek Formation of the Bozeman Supergroup (Fig. 1; Hanneman and Wideman, 1991). MBJ was dated to 11.2-9.5 Ma by Retallack (2007) based on an overlaying caprock recognized by regional sequence stratigraphy (Hanneman and Wideman 2006) and two dated ash layers (Fritz et al., 2007; Retallack, 2007). Samples discussed herein were collected directly above an ash dated to $10.42 \mathrm{Ma}$, which is at the $71 \mathrm{~m}$ level in Retallack’s (2007) section. Retallack (2007) and Hamer (2009) previously described both weakly developed (Entisol and Inceptisol-like) and moderately developed (Mollisol-like) paleosols on the basis of horizonation, color changes, grain size changes, burrows, and root traces (both 
organic and rhizoliths). Modern Mollisols are associated with grassland ecosystems, whereas Entisols and Inceptisols may be found in a variety of ecosystem types (e.g., Sheldon and Tabor, 2009). All of the selected paleosols have fine-coarse sand grain sizes, meaning that little isotopic difference is expected as a function of depth between the A horizon and upper B horizon. Based on the depth to paleosol Bk horizons, Retallack (2007) reconstructed a mean annual precipitation (MAP) of $389 \pm 85 \mathrm{~mm} \mathrm{yr}^{-1}$ for the duration of deposition at MBJ; sub-sampling that data to include the five paleosols preserved above and below the sampling interval described herein yields a statistically indistinguishable MAP of $369 \pm 73 \mathrm{~mm} \mathrm{yr}^{-1}$, suggesting long-term, stable paleoprecipitation regime. Retallack (2007) reconstructed a mean annual temperature (MAT) of $10 \pm 4^{\circ} \mathrm{C}$ for the site based on paleosol geochemistry (Sheldon et al., 2002) and Hamer (2009) reconstructed a MAT of $9 \pm 4{ }^{\circ} \mathrm{C}$ using the same proxy, and $11 \pm 2^{\circ} \mathrm{C}$ using a paleosol orderspecific proxy for Inceptisols. As with MAP, reconstructed MAT suggests long-term stability. Paleosol samples were collected both vertically within a short stratigraphic section (Fig. 2), and laterally to measure localized spatial heterogeneity and vegetation change through time and space, respectively. Lateral section samples were taken at 0,12 , and $22 \mathrm{~m}$ intervals in the A horizon of the upper and lower paleosols. Vertical section samples were taken from the upper and lower parts of the caprock, and the A and B horizons of the two paleosols. Isotopic Analyses

Samples were prepared for $\delta^{13} \mathrm{C}_{\text {org }}$ analysis at the University of Michigan following the method outlined in Cotton et al. (2012). Briefly, samples were ultrasonicated in methanol to remove modern organic material, and treated with a $7 \% \mathrm{HCl}$ solution on a $50^{\circ} \mathrm{C}$ hotplate to remove calcium carbonate $\left(\mathrm{CaCO}_{3}\right)$. The remaining material was rinsed in deionized water and dried, before being crushed and loaded in tin capsules and analyzed using a Costech Elemental 
Analyzer coupled to a Delta V+ isotope ratio mass spectrometer. Results are reported in delta notation relative to the VPDB scale. External precision was maintained at $<0.1 \%$.

The burning of fossil fuels makes the modern atmospheric $\delta^{13} \mathrm{C}$ value ( -8\%) nonanalogous with the geologic past, so we adjusted our mixing line by $+2 \%$ based on a reconstructed $\delta^{13} \mathrm{C}_{\mathrm{atm}}$ value of -6\%o for 11-9 Ma from Tipple et al. (2010). Thus, the $\mathrm{C}_{3}$ endmember is defined as $-25 \%$ and the $\mathrm{C}_{4}$ end-member as $-11 \%$ for both vegetation and paleosol $\mathrm{A}$ horizon organic matter. Analytical uncertainty in isotopic measurements of $0.1 \%$ equates to $0.7 \%$ uncertainty in reconstructed $\% \mathrm{C}_{4}$ and replicate uncertainty in isotopic measurements of $0.24 \%$ o equates to $1.7 \%$ uncertainty in reconstructed $\% \mathrm{C}_{4}$; uncertainty in $\delta^{13} \mathrm{C}_{\mathrm{atm}}$ is much larger than measurement uncertainty and has been plotted throughout to be conservative.

Phytoliths

Phytoliths were extracted from $~ 1 \mathrm{~g}$ of sediment at the University of Michigan following Strömberg $(2003,2005)$, using heavy liquid floatation with zinc bromide (ZnBr). Phytoliths were mounted onto slides using Cargille Meltmount (refraction index 1.534) mounting medium and immersion oil (Cargille Non-Drying Immersion Oil Type A) for rotation to characterize the 3D and surface morphology of, in particular, grass phytoliths, and viewed under a light microscope at 1000x magnification. Morphotypes were then identified following the scheme established in Strömberg (2003), and using a modern reference collection compiled by S.Y. Smith at University of Michigan for comparison. Diagnostic morphotypes were grouped broadly into two functional groups, so-called forest indicators (FI; phytolith morphotypes which are commonly produced by trees and other plants associated with forests; see Strömberg, 2004) and grasses (i.e., grass silica short cells, GSSCs), to determine vegetation composition; morphotypes with compound variables of CONI/MONO, GRASS/MONO-ND, GRASS-D, and OTH (from Strömberg (2003), 
182 see also Miller et al. (2012) for details; Supplemental Table 2, 3) were excluded from analysis 183 due to, among other things, uncertainty about the functional plant groups they represent 184 (discussed in Strömberg, 2004; McInerney et al., 2011). Non-plant biogenic silica, including 185 diatoms, sponge spicules, and chrysophyte cysts (DSCs), was also counted to provide 186 information on hydrologic conditions (Piperno, 1988; Clarke, 2003). Approximately 200 187 diagnostic phytoliths were counted and classified per sample (Supplemental Table 2). Grass silica short cells (GSSCs) were classified according to Strömberg (2003, 2005) and 189 combined into broad taxonomic and ecological groups: closed-habitat grasses (BAMB/B), cool190 temperate open-habitat grasses in the Pooideae (POOID-D, POOID-ND), tropical open-habitat 191 grasses in the PACMAD clade, including the mainly $\mathrm{C}_{4}$ Panicoideae (PANI), the exclusively $\mathrm{C}_{4}$ 192 (Ingram et al., 2011) Chloridoideae (CHLOR), and other $\mathrm{C}_{3} / \mathrm{C}_{4}$ PACMADs (PACMAD-GEN), 193 as well as unknown or unclassified GSSCs (OTHG). Current GSSC classification is limited to 194 identifying members of panicoids and chloridoids; in addition, it remains unclear how GSSC 195 production varies between $\mathrm{C}_{3}$ and $\mathrm{C}_{4}$ grasses (discussion in McInerney et al., 2011).

196 Nevertheless, modern phytolith studies have shown that grass silica short cell assemblages 197 reflect $\mathrm{C}_{3}$ vs. $\mathrm{C}_{4}$ dominance in many ecosystems (e.g., Fredlund and Tieszen, 1994, 1997; 198 Barboni et al., 2007; Bremond et al., 2008; Hyland et al., 2013). To account for some of these 199 uncertainties, we follow Strömberg and McInerney (2011) in calculating a minimum and 200 maximum estimate of $\mathrm{C}_{4}$ grasses using, respectively the number of panicoid and chloridoid 201 GSSCs (PANI + CHLOR) and the total number of PACMAD GSSCs divided by the sample's 202 total number of diagnostic phytoliths (forest indicators + grass silica short cells). Ninety-five 203 percent confidence intervals (unconditional case; see Strömberg, 2009) for these estimates were 
204 calculated using bootstrapping in R software (script available from authors upon request; R

205 Development Core Team, 2013).

206 Results

207 Stratigraphy and Paleosols

Detailed paleosol descriptions can be found in Retallack (2007) and Hamer (2009), and

209 are summarized here. Retallack (2007) previously identified four types of paleosols at MBJ, his

210 Aikkwi, Aisen, Antsi, and Tatsah pedotypes. Each of the four pedotypes is characterized by

211 preserved horizonation (i.e., A and B horizons), including Bk horizons of various depths, and

212 would key out at Entisol- or Inceptisol-like using USDA terminology. Hamer (2009) also

213 identified an additional paleosol type - an Inceptisol-like paleosol with granular peds in the A

214 horizon as in a Mollisol, and either a weakly developed or non-existent Bk horizon. The caprock

215 paleosols (Fig. 3) represent Retallacks's (2007) Antsi pedotype (A-Bk-C; Bk <50 cm below

216 surface), and "lower" and "upper" paleosols represent the mollic Inceptisol-like paleosol (A-Bw,

217 no Bk horizon) identified by Hamer (2009). The cap rock was previously identified by

218 Hanneman and Wideman (2006) as a calcic pedocomplex (composite paleosols) that represents a

219 regional sequence stratigraphic marker bed in their Sequence 4. Composite paleosols are

220 typically preserved in rapidly aggrading depositional successions and Mollisol-like paleosols on

221 quiescent floodplains, thus, the identified paleosols represent both periods of both rapid and slow

222 basin filling regimes. Some type of soils/paleosols, such as Alfisols, exhibit the potential for

223 representational bias for grass phytoliths (i.e., overestimate the proportion of grasses). However,

224 neither Mollisols nor Entisols exhibit any biasing, so phytolith results from the paleosols at MBJ

225 do not require a taphonomic correction (Hyland et al., 2013).

226 Trace Fossils 
Back-filled burrows (Fig. 2A) and organic root traces (Fig. 2B) were most abundant in

228 the caprock, but also present in both the lower and upper paleosols. Root traces occasionally

229 preserved whole corticoid cells (Fig. 2C), but were generally present as kerogenized organic

230 rootlets. A large ant nest trace fossil (e.g., Hasiotis, 2004; Hamer et al., 2007) was also found in

231 the caprock (Fig. 2D; Hamer, 2009) and in a low bluff stratigraphically below the main section.

232 Isotopic ratios

233

$\delta^{13} \mathrm{C}$ values of paleosol soil organic matter ranged from $-25.8 \%$ to $-23.2 \%$ with a mean

234 of $-24.3 \pm 0.8 \%(1 \sigma)$, corresponding to $0-12.8 \% \mathrm{C}_{4}$ with a mean of $5.6 \pm 4.6 \%$ (Supplementary

235 Table 1). Figure 3 plots $\delta^{13} \mathrm{C}$ values by stratigraphic position, as well as the corresponding

236 percentage $\mathrm{C}_{4}$ composition calculated using the two-component mixing line described above.

237 One sample yielded a value that would imply negative percent $\mathrm{C}_{4}$ (i.e., $\delta^{13} \mathrm{C}<-25 \%$ ), which was 238 readjusted to zero.

239 Phytoliths

240 All sampled stratigraphic levels yielded phytoliths, which ranged from poorly to well

241 preserved. Five of 12 samples were too poorly preserved for a quantitative count; these were

242 instead analyzed qualitatively for absence or presence of key indicator phytoliths (Supplemental

243 Table 2, 3). The remaining seven samples yielded, on average, $31.3 \pm 3.3(1 \sigma)$ morphotypes

244 (range: 26-36), significantly more than at older southwestern Montana sites (Miller et al., 2012,

245 Middle Eocene: $19.6 \pm 3.3(1 \sigma)$ morphotypes, range 14-25). MBJ has a lower diversity of total

246 FI morphotypes and higher diversity of total GSSC compared to THA (total 26 FI morphotypes

247 and 9 GSSC morphotypes vs. total 11 FI morphotypes and 23 GSSC morphotypes). There was

248 little lateral variation between samples from the same horizon (Fig. 3), and no charcoal was

249 observed. 
251

252

253

254

255

256

257

258

259

260

261

262

263

264

265

266

267

268

269

270 271 (Supplemental Table 2).

272

\section{Discussion}

chrysophytes (Fig. 4A-F), were present in all samples and contributed on average $5.3 \pm 2.9 \%$

(range: 1.6-10.8\%) of total counted biosilica (Supplemental Table 2). All seven quantitatively counted samples were dominated by GSSCs, potential grass (GRASS/MONO-ND), and nondiagnostic OTH morphotypes, suggesting that many of the non-diagnostic forms were produced by grasses. Common non-diagnostic phytoliths included elongates (Elo-1; Fig. 4G), epidermal cells typical of grasses (Epi-9; Fig. 4H), parenchyma cells (M-8; Fig. 4H, M), trichome fillings (Tri-8, Fig. 4I), and rectangular plates (Blo-2; Fig. 4J).

Considering only diagnostic forest indicator (FI) and GSSC (grass) phytoliths, all samples were strongly indicative of grass-dominated ecosystems, with a ground cover made up almost exclusively of $\mathrm{C}_{3}$ open-habitat grasses (mean: $95.2 \pm 1.7 \%$, range: $92.5-97.5 \%$ ). Phytoliths from potential $\mathrm{C}_{4}$ grasses contributed only minimally, yielding on average a minimum percent $\mathrm{C}_{4}$ of $2.6 \pm 0.9 \%$ (range: $1.6-4.1 \%$ ) and a maximum percent $\mathrm{C}_{4}$ of $3.3 \pm 0.9 \%$ (range: 2.1-4.7\%) when including all PACMAD forms in the estimate. Potential $\mathrm{C}_{4}$ morphotypes were limited to panicoid-type bilobates and crosses (BI-8, not pictured; crosses: Fig. 4W-Y) and PACMAD-GEN-type bilobates (BI-5, not pictured; BI-7, Fig. 4V). C 3 GSSCs were dominated by pooid-type conical and keeled rondels, Stipa and rounded/rectangular-top bilobates, and crenates (Fig. 4P-U). FI morphotypes consisted mainly of small rugulose spheres (Cl-7, Fig. 4L) and rare palm phytoliths (Clm-2a, Fig. 4N), which were present in most samples. Qualitatively analyzed samples included pooid-type GSSCs, potential grasses (CONI/MONO and GRASS-MONO-ND), and non-diagnostic OTH forms, but not identifiable grass phytoliths from potential $\mathrm{C}_{4}$ grasses 
Comparison of isotope and phytolith estimates of $\mathrm{C}_{4}$ in the Miocene of Montana

Results from both carbon isotopic ratios and phytolith assemblages suggest limited amounts of $\mathrm{C}_{4}$ vegetation (Figs. 3, 5) at the MBJ locality. Isotopic ratios yielded a slightly higher average $\mathrm{C}_{4}$ composition compared to phytolith assemblage analysis $(5.6 \pm 4.6 \%$ and $2.6-3.3 \%$, respectively), but both types of estimates are within error range of each other for most samples (Fig. 5). Phytolith assemblage values also show much less variation (range: 1.6-4.7\%) compared to values calculated based on isotopic data (range: $0-13 \%$ ). As a result, there is almost no statistical correlation between the two estimates of $\mathrm{C}_{4}$ abundance on the landscape. The nearby TFF site (Cotton et al., 2012) yielded a similar result, with isotopic results indicating a slightly higher proportion of $\mathrm{C}_{4}$ vegetation than phytoliths for one sample, a close match for another, and one sample where the phytoliths indicated a higher proportion of $\mathrm{C}_{4}$ (Figs. 5, 6). However, the fact that both methods result in overall similar reconstructions of relative abundance of $\mathrm{C}_{4}$ biomass (i.e., <15\%), and at two different geographic localities, suggests that the inferred overall proportion of $\mathrm{C}_{4}$ vegetation is robust. In addition, although $\mathrm{C}_{4}$ plants are known from 19 angiosperm families, grasses are the most widespread $\mathrm{C}_{4}$ taxa (Sage, 2004; Sage et al., 2011). The close correspondence between inferred $\mathrm{C}_{4}$ from GSSC phytoliths and isotopic data supports the interpretation that grasses were the only $\mathrm{C}_{4}$ plants in Montana at this time.

In their study aimed at understanding Rocky Mountain uplift history using $\delta^{18} \mathrm{O}$ values of pedogenic carbonates, Chamberlain et al. (2012) also published isotopic analyses of paleosol carbonates and carbonate cements from MBJ where the $\delta^{13} \mathrm{C}_{\text {carb }}$ values range from -3.4 to $-4.5 \%$ o $(n=16)$. Using the same assumptions as were used to reconstruct the proportion of $\mathrm{C}_{4}$ plants from the $\delta^{13} \mathrm{C}_{\text {org }}$ data, it is possible to reconstruct the proportion of $\mathrm{C}_{4}$ plants that would be

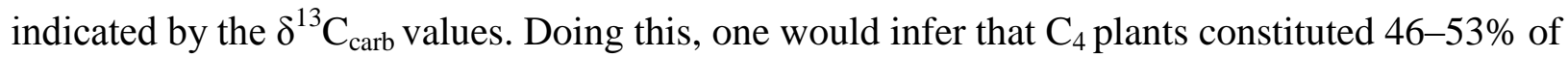


296 vegetation, which is clearly at odds with both the phytolith and $\delta^{13} \mathrm{C}_{\text {org }}$ data. Cotton et al. (2012)

297 previously noted a similar discrepancy for the TFF site, where $\delta^{13} \mathrm{C}_{\text {carb }}$ values apparently

298 indicated a much higher proportion of $\mathrm{C}_{4}$ plants than either phytoliths or $\delta^{13} \mathrm{C}_{\text {org }}$ data. The fact

299 that samples from this study and from Chamberlain et al. (2012) were not all from exactly the

300 same paleosols within the MBJ section (i.e., some data in Chamberlain et al. 2012 are also from

301 paleosols stratigraphically above and below the paleosols in this study) could account for some

302 of the discrepancy. However, some of their isotopic measurements come from the caprock

303 paleosols (Fig. 3), and because of the relatively rapid depositional rate (Retallack, 2007) none of

304 these data are more than a few hundred thousand years younger or older, meaning that it is still

305 possible to evaluate how reasonable the constraints derived from the $\delta^{13} \mathrm{C}_{\text {carb }}$ values are on the

306 proportion of $\mathrm{C}_{4}$ plants at this site. Pedogenic carbonates that formed in equilibrium with soil-

307 respired $\mathrm{CO}_{2}$ should be $+14-17 \%$ (typically $+15.5 \%$ ) relative to organic matter from the same

308 soil or paleosol (given as $\Delta^{13} \mathrm{C}$; Cerling and Quade, 1993). Using the mean $\delta^{13} \mathrm{C}_{\text {org }}$ value of -

$30924.3 \%$, none of the carbonates preserved at MBJ were formed in isotopic equilibrium, with $\Delta^{13} \mathrm{C}$

310 values ranging from +19.8 to +20.9 . Even if one assumes instead that the highest $\delta^{13} \mathrm{C}_{\text {org }}$ value of

$311-23.2 \%$ was the most representative, the minimum $\Delta{ }^{13} \mathrm{C}$ value would be +18.7 , which is still

312 substantially out of equilibrium. The degree of disequilibrium is consistent with groundwater

313 affected or diagenetically altered carbonates (Tabor et al., 2013). Thus, the carbonates at MBJ,

314 like at TFF, can be considered unreliable for reconstructing past vegetation. Because

315 paleoelevation studies rely on the relative changes in $\delta^{18} \mathrm{O}_{\text {carb }}$ rather than the absolute value, this

316 result does not call into question Chamberlain et al.'s (2012) results, but instead suggests that

317 workers should be careful when applying $\delta^{13} \mathrm{C}_{\text {carb }}$ values to understand the proportion of $\mathrm{C}_{4}$

318 plants in the absence of other proxies that can rule out pedogenic or diagenetic alteration. 
Regional vegetation heterogeneity in Montana

At MBJ (11.2-9.5 Ma) there is evidence for low levels $(<15 \%)$ of $\mathrm{C}_{4}$ vegetation in an otherwise $\mathrm{C}_{3}$ open-habitat ecosystem. In contrast, Cotton et al. (2012) found higher and more variable $\mathrm{C}_{4}$ presence $(0-35 \%)$ at a penecontemporaneous $(10.2-8.9 \mathrm{Ma})$, nearby (Fig. 1) site further south (Fig. 6). Neither site demonstrates a secular (i.e., temporal) trend. These differences suggest that there was significant regional heterogeneity in $\mathrm{C}_{4}$ distribution-as has been noted in other late Miocene ecosystems (Behrensmeyer et al., 2007) — but also that $\mathrm{C}_{4}$ vegetation had become more abundant on parts of the landscape in the late Miocene compared to earlier times, pointing to expansion of $\mathrm{C}_{4}$ vegetation during this time. One hypothesis might be that these changes were driven by a changing climate. However, estimates of MAT and MAP from TFF and this site $\left(385 \pm 147 \mathrm{~mm} \mathrm{yr}^{-1}\right.$ vs. $369 \pm 73 \mathrm{~mm} \mathrm{yr}^{-1}$, and $9.2 \pm 0.9{ }^{\circ} \mathrm{C}$ vs. $9-11^{\circ} \mathrm{C}$, respectively; Retallack, 2007; Hamer, 2009; Cotton et al., 2012), are overlapping, and global $\mathrm{CO}_{2}$ was constant at the time (Pagani et al., 1999; Bolton and Stoll, 2013; Zhang et al., 2013). Therefore, it seems unlikely that changes in overall aridity, temperature, or atmospheric $\mathrm{CO}_{2}$ were responsible for this increase in variability.

The presence but consistently very low abundance of GSSCs highly diagnostic of chloridoids among potential $\mathrm{C}_{4}$ grasses in the middle and late Miocene of Montana (Strömberg, 2005; Cotton et al., 2012) supports the idea that changes in aridity were not important for higher $\mathrm{C}_{4}$ values at TFF compared to MBJ. Chloridoid grasses tend to be associated with more arid and open environments compared to other $\mathrm{C}_{4}$ grasses (in the Panicoideae; Taub, 2000; Liu et al., 2012), and Strömberg and McInerney (2011) used observed increases in chloridoid relative frequency (coupled with decreasing palm abundance) to argue for late Miocene drying in the central Great Plains. The most abundant GSSCs reflective of potential $\mathrm{C}_{4}$ grasses at MBJ are 
342 indicative of panicoids, which show an overall preference for wetter habitats (Taub, 2000; Liu et 343 al., 2012).

344 Instead of broad-scale changes in climate (i.e., global climate change), we suggest that 345 differential expansion of $\mathrm{C}_{4}$ grasses was driven by one or more local factors, such as disturbance 346 (fire regime, herbivory, sediment deposition), topography/elevation (see below), potentially in 347 combination with climatic seasonality (see below). Previous work has pointed to the importance 348 of disturbance, in particular fire, in maintaining today's savanna vegetation in many regions (e.g., 349 Lehmann et al., 2011). A simulation of fire regimes by Scheiter et al. (2012) for Africa (with vast 350 areas of generally warmer and more arid conditions than in Montana) found that fire contributed 351 mainly to the invasion of grasses $\left(C_{4}\right.$ and $\left.C_{3}\right)$ into $\left(C_{3}\right)$ forests, whereas the expansion of $C_{4}$ 352 grasses at the expense of $\mathrm{C}_{3}$ grasses was driven by the physiological advantages of $\mathrm{C}_{4}$ grasses in 353 hot, arid, low- $\mathrm{CO}_{2}$ environments. Therefore, if fire was an important driver of local $\mathrm{C}_{4}$

354 distribution, it should be reflected principally in the abundance of trees over grasses $\left(\mathrm{C}_{3} / \mathrm{C}_{4}\right)$, with 355 the younger site (TFF) having a lower frequency of forest indicators. Data from TFF shows that 356 high relative $C_{4}$ biomass, reconstructed based on $\delta^{13} C_{\text {org }}$ values, only occurs in samples with low 357 relative abundance of forest indicator phytoliths (i.e., in more open habitats; Strömberg et al., 358 2012). However, overall, TFF has a higher inferred tree cover than MBJ, which is not consistent 359 with the hypothesis that fire influenced the expansion of $\mathrm{C}_{4}$ grasses in southwestern Montana. 360 The charcoal record needed to further test this idea has yet to be collected.

361 The degree of within-site "patchiness" also differed between MBJ and TFF. When 362 heterogeneity in paleovegetation was reconstructed through lateral sampling at the scale of tens 363 of meters, MBJ (Fig. 3) shows consistently low $\mathrm{C}_{4}$ abundance across the landscape, whereas 364 there seems to have existed considerable spatial variability at TFF (Cotton et al., 2012; their Figs. 
5, 6). Although it is possible that more lateral sampling at MBJ would have revealed similar patchiness, the fact that the TFF site exhibits a wide range of $\mathrm{C}_{4}$ abundance values laterally as well as vertically (i.e., temporally) suggests that the site overall records substantially more pronounced variation ("patchiness"). Previous work in Montana has indicated that such landscape patchiness may be linked to disturbance through stream avulsion (Miller et al., 2012). Under this scenario, the more variable TFF site would reflect a more highly disturbed ecosystem.

The MBJ section is very short, complicating an in-depth study of depositional mode (e.g., stream avulsion rate). However, the only major change in depositional mode identified by Retallack's (2007) study of a longer section is the cap rock within the short MBJ section, which suggests that depositional environment changes did not impact $\mathrm{C}_{4}$ abundance there.

\section{Paleoelevation implications}

Local reconstructed paleoclimate conditions are cool and dry (Retallack, 2007; Hamer, 2009), consistent with a dry scrubland (Gulbranson et al., 2011). At both TFF and MBJ, very few FI phytoliths were identified, and relatively low levels of $\mathrm{C}_{4}$ are indicated by combined isotope and phytolith records, with less than $10 \% \mathrm{C}_{4}$ indicated for most of the two records, and lower reconstructed $\mathrm{C}_{4}$ at $\mathrm{MBJ}$ than at TFF. Thus, both the paleovegetation and paleoclimatic results are consistent with a relatively open, relatively sparse vegetative cover. This paleo- $\mathrm{C}_{4}$ distribution closely matches that modern $\mathrm{C}_{4}$ distribution in Montana, where present-day TFF has less than $20 \% \mathrm{C}_{4}$ plants and modern day $\mathrm{MBJ}$ has less than $10 \% \mathrm{C}_{4}$ plants (Epstein et al., 2002). This suggests that a distribution of $\mathrm{C}_{4}$ plants similar to the modern may have been established by at least the middle Miocene. Today the distribution of $\mathrm{C}_{3}$ and $\mathrm{C}_{4}$ grasses along elevational gradients is highly predictable, and linked to temperature (e.g., in South America, $\mathrm{C}_{4}$ plants are absent at elevations > 2500 meters; Cavagnaro, 1988; Cabido et al., 1997). Although the exact 
388 elevation of $\mathrm{C}_{4}$ absence appears to differ among continents and regions (e.g., at $2100 \mathrm{~m}$ in China;

389 Li et al., 2009), a similar relationship with elevation has been observed in China (Li et al., 2009),

390 Central Asia (Taft et al., 2011), on the Arabian Peninsula (Masrahi et al., 2012), and in the

391 southwestern part of the United States (Van de Water et al., 2002). The similarities in $\mathrm{C}_{4}$ biomass

392 between the late Miocene and today of Montana therefore suggest that the paleo-elevation of

393 Montana was also similar. Cotton et al. (2012) reported a mean modern (Preindustrial) soil

$394 \delta^{13}$ Corg value of $-24.3 \%$ for soils at a similar elevation and nearby to the TFF site, which

395 compared favorably with their Miocene mean value of $-23.9 \%$, further supporting the idea that

396 the Miocene and modern $\mathrm{C}_{4}$ distributions were analogous and were probably controlled by

397 similar ecological factors. This hypothesis finds independent support in a study by Chamberlain

398 et al. (2012). They compiled a variety of isotopic records both in space and in time and found

399 that there was little evidence for uplift after $15 \mathrm{Ma}$ ago in Montana, and that regional

400 paleoelevation was most likely over $2 \mathrm{~km}$ at the time of MBJ's deposition.

401 North American spread of grasslands

402

A body of paleobotanical and isotopic evidence now indicates that, during the Eocene,

403 Montana was covered in paratropical forests with $\mathrm{C}_{3}$, potentially open-habitat grasses growing at

404 disturbed sites (Strömberg, 2003, 2005; Miller et al., 2012). Macrofossil evidence from the latest

405 Eocene and early Oligocene Ruby and Beaverhead basin floras shows these forests persisted,

406 becoming dominated by coniferous and temperate angiosperm elements throughout the

407 Paleogene (Becker, 1960, 1961, 1966, 1969, 1972, 1973; Lielke et al., 2012). By the late early-

408 middle Miocene, these forests had been replaced by open-habitat woodlands dominated by $\mathrm{C}_{3}$

409 grasses with a minor $\mathrm{C}_{4}$ component (Strömberg, 2003, 2005; Cotton et al., 2012; this study).

410 Paleobotanical and isotopic data from other parts of the continental interior - the central and 
411 southern Great Plains (see Table 1) - indicate a similar pattern of vegetation change. However,

$412 \quad \delta^{13} \mathrm{C}$ of ungulate tooth enamel has classically been interpreted as showing a latitudinal gradient

413 in the emergence of $\mathrm{C}_{4}$ dominated habitats (e.g., Passey et al., 2002). Whereas phytolith

414 assemblage data show the presence of PACMAD grasses in general and recent work on leaf

415 waxes indicates that $\mathrm{C}_{4}$ grasses in particular were present in the early Oligocene of the Great

416 Plains (Strömberg, 2005; Tipple and Pagani, 2010), there is no clear evidence for PACMADs in

417 the Paleogene of Montana (Strömberg, 2005; Miller et al., 2012). This contrast in PACMAD

418 abundance supports the notion that $\mathrm{C}_{4}$ grasses reached more southern areas in the Great Plains

419 first and, hence, that a latitudinal gradient in vegetation existed within the continental interior

420 during the Cenozoic (Leopold and MacGinitie, 1972; Strömberg, 2005). In contrast, a recent

421 comparison of ungulate functional morphology, isotopic and phytolith data found no such

422 gradient in the late Miocene ( 7 Ma; Fraser and Theodor, 2013). Other late Miocene Great

423 Plains sites (Fox and Koch, 2003; Strömberg and McInerney, 2011; Fox et al., 2012) indicate

$424 \quad 10-30 \%$ and $0-20 \% \mathrm{C}_{4}$ composition (Table 1), respectively, compared to modern values of $75 \%$

425 and $30-40 \% \mathrm{C}_{4}$ (Epstein et al., 2002), respectively, indicating significant change in regional

426 vegetation composition since the late Miocene. This shift was accompanied by, or possibly

427 driven by, substantial cooling and aridification (Strömberg and McInerney, 2011; Fox et al.,

428 2012). In contrast, Montana saw little change in $C_{4}$ abundance over the same period (late

429 Miocene: $0-15 \% \mathrm{C}_{4}$, present: $10-20 \% \mathrm{C}_{4}$ ), as noted above. This pattern suggests that the lower

430 elevation Great Plains sites have experienced substantially greater shifts in vegetation

431 community composition than the higher elevation Montana sites since the late Miocene.

432 Regional Montana record in a global context 

ecological drivers rather than a global climatic trigger for changing $\mathrm{C}_{4}$ abundance, which is also observed in Pakistan (Behrensmeyer et al., 2007). In Montana, measurable amounts (5-30\%) of

$436 \mathrm{C}_{4}$ grasses appear to have existed millions of years prior to the late Miocene-early Pliocene 437 global spread of $\mathrm{C}_{4}$ grasslands, usually as minor components of open, $\mathrm{C}_{3}$ grass-dominated 438 habitats. The earliest widespread $\left(\mathrm{C}_{3}\right)$ grasslands were previously thought to be in Argentina by 439 the middle Eocene (e.g., Jacobs et al., 1999; Strömberg, 2011), and the earliest widespread $\mathrm{C}_{4}$ 440 vegetation in at low latitudes across several continents by late Miocene (8-5 Ma; Edwards et al., 441 2010). Edwards et al.'s (2010) global compilation of estimates of the timing of $\mathrm{C}_{4}$ origin and 442 expansion based on pedogenic carbonates, ungulate tooth $\mathrm{C}$ isotopes, and phytoliths, revealed major difference in the tempo and mode of $\mathrm{C}_{4}$ expansion even at similar latitudes. More recent 444 work (post-2010 literature summarized in Table 1) has further developed our understanding of 445 the geologic history of grassland ecosystems, highlighting the regional nuance pointed out by 446 Edwards et al. (2010), in particular, depending on which proxy is used, emphasizing the need for 447 multiproxy reconstructions like the one presented herein. For example, Cotton et al. (2014) found 448 significant differences in regional $\mathrm{C}_{4}$ abundance between late Miocene-mid-Pliocene sites at 449 different elevations in northern Argentina. In Asia, Jia et al. (2012) and Singh et al. (2013) found 450 evidence for $\sim 20 \% \mathrm{C}_{4} 3-6 \mathrm{Ma}$ prior to previous estimates of $\mathrm{C}_{4}$ expansion in the Tibetan Plateau 451 region, although studies for the same region by Leier et al. (2009), Martin et al. (2011), Charreau 452 et al. (2012), and Zhang et al. (2012) found no such evidence. In Inner Mongolia, Zhang et al. 453 (2009) found little evidence for $\mathrm{C}_{4}$ pre-8 Ma, and mixed $\mathrm{C}_{3}-\mathrm{C}_{4}$ post- $8 \mathrm{Ma}$. In both Eastern and 454 Western Africa, studies of mammalian tooth enamel indicated $\mathrm{C}_{4}$ expansion in the range of 7-5 455 Ma as opposed to the 10 Ma found by earlier studies of in Kenya (Uno et al., 2011). Taken 
456 together, these studies emphasize both local and regional variation in $\mathrm{C}_{4}$ vegetation prior to the

457 global late Miocene-Pliocene expansion event (Table 1). In particular, prior to the latest Miocene,

458 the presence and abundance of $\mathrm{C}_{4}$ vegetation, and the composition of coexisting $\mathrm{C} 3$ vegetation

459 (trees/shrubs vs. grasses) seems to have been spatially and temporally very variable. Generally

460 speaking, areas of low paleoelevation and drier climates appear to have maintained a low

461 abundance of $\mathrm{C}_{4}$ plants first, but in some regions their subsequent rise to dominance can be

462 linked to climatic changes (e.g., Kansas; Fox et al., 2012), whereas in other areas such as

463 Montana (this study; see Retallack, 2007 for long-term climate changes) climatic and tectonic

464 conditions were stable over millions of years. These findings underscore the importance of local

465 factors such as seasonality, topography/elevation, fire regime, and biological community

466 composition on $\mathrm{C}_{4}$ distribution (or combinations thereof), as opposed to singular global or

467 regional controls.

468 Conclusions

469 Organic carbon isotopes and phytolith assemblages are independent and complementary

470 techniques for reconstructing past vegetation. In this study of the late Miocene (11.2-9.5 Ma)

471 MBJ locality, the techniques combined suggested an open-habitat, $\mathrm{C}_{3}$ dominated grassland with a

472 small $\mathrm{C}_{4}$ component $(<15 \%)$ during a period of arid climate, similar to the present ecosystem.

473 When combined with other records from the region, these results support the idea that $\mathrm{C}_{3}$ closed

474 forests were replaced by $\mathrm{C}_{3}$ grasslands with a small $\mathrm{C}_{4}$ component in Montana as well as in the

475 Great Plains (Strömberg, 2005); similar patterns have been suggested for other parts of the world

476 as well (Edwards et al., 2010; Strömberg, 2011). Furthermore, in most areas around the world,

$477 \mathrm{C}_{4}$ vegetation was present at low to moderate levels for millions of years prior to global

478 expansion with both variable timing of the onset of and ultimate scale of $\mathrm{C}_{4}$ expansion. Similar 
479 heterogeneity is evident both at the local and regional scale when comparing

480 penecontemporaneous sites in Montana. Patchiness in $\mathrm{C}_{4}$ distribution and expansion even during

481 times of climatic quiescence during the Miocene suggests that local and regional factors such as

482 fire regime, biodiversity, topography, and seasonality, which affect modern grassland

483 distribution, were also important factors in historic grassland expansion and distribution.

\section{Acknowledgements}

485 The authors would like to thank Tess Nugent and Tim Gallagher (University of Michigan) for

486 assistance with isotopic analyses. SYS would like to acknowledge the support of the Michigan

487 Society of Fellows. This research was supported by NSF Award \#1024535 to NDS and SYS;

488 NSF Award \#1024681 to CAES. 


\section{References Cited}

Asner, G.P., Elmore, A.J., Olander, L.P., Martin, R.E., Harris, T., 2004. Grazing systems, ecosystem responses, and global change. Ann. Rev. Environ. Res. 29, 261-299.

Barboni, D., Bremond, L., Bonnefille, R., 2007. Comparative study of modern phytolith assemblages from inter-tropical Africa. Palaeogeogr. Palaeoclimatol. Palaeoecol. 246, $454-470$.

Becker, H.F., 1960. Additions to the Tertiary Ruby paper shale flora of southwestern Montana. Bull. Torrey. Bot. Club 87, 386-396.

Becker, H.F., 1961. Succulent display in Israel and Sweden. Cactus and Succ. Jour. 33, 71-73.

Becker, H.F., 1966. Additions to and revision of the Oligocene Ruby Paper Shale flora of southwestern Montana. Univ. Mich. Mus. Paleontol. Contrib. Mus. Paleontol. 20, 89-119.

Becker, H.F., 1969. Fossil plants of the Tertiary Beaverhead Basins in southwestern Montana. Palaeontographica B 127:1-142 + 44 pls.

Becker, H.F., 1972. The Metzel Ranch Flora of the Upper Ruby River Basin, southwestern Montana. Palaeontographica B 141:1-61 + 16 pls.

Becker, H.F., 1973. The York Ranch Flora of the Upper Ruby River Basin, southwestern Montana. Palaeontographica B 143:18-93 + 40 pls.

Bedaso, Z.K., Wynn, J.G., Alemseged, Z., Geraads, D. 2013. Dietary and paleoenvironmental reconstruction using stable isotopes of herbivore tooth enamel from middle Pliocene Dikika, Ethiopia: Implication for Australopithecus afarensis habitat and food resources. 
Behrensmeyer, A.K., Quade, J., Cerling, T.E., Kappelman, J., Khan, I.A., Copeland, P., Roe, L., Hicks, J., Stubblefield, P., Willis, P., Latorre, C., 2007. The structure and rate of late Miocene expansion of $\mathrm{C}_{4}$ plants: evidence from lateral variation in stable isotopes in paleosols of the Siwalik Group, northern Pakistan. Bull. Geol. Soc. Am. 119, 1486-1505.

Bolton, C.T., Stoll, H.M., 2013. Late Miocene threshold response of marine algae to carbon dioxide limitation. Nature 500, 558-562.

Bonnefille, R. 2010. Cenozoic vegetation, climate changes and hominid evolution in tropical Africa. Global and Planetary Change 72, 390-411.

Bremond, L., Alexandre, A., Wooller, M.J., Hely, C., Williamson, D., Schafer, P.A., Majule, A., Guiot, J., 2008. Phytolith indices as proxies of grass subfamilies on East African tropical mountains. Glob. Plan. Ch.61, 209-224.

Cabido, M., Ateca, N., Astegiano, M.E., Anton, A.M., 1997. Distribution of $\mathrm{C}_{3}$ and $\mathrm{C}_{4}$ grasses along an altitudinal gradient in Central Argentina. J. Biogeog. 24, 197-204.

Cavagnaro, J.B., 1988. Distribution of $\mathrm{C}_{3}$ and $\mathrm{C}_{4}$ grasses at different altitudes in a temperate arid region of Argentina. Oecologia 76, 273-277.

Cerling, T. E., Harris, J. M., 1999. Carbon isotope fractionation between diet and bioaptite in ungulate mammals and implications for ecological and paleoecological studies. Oecologia 120, 347-363.

Cerling, T.E., Quade, J., 1993. Stable carbon and oxygen isotopes in soil carbonates, in Swart, P.K., Lohmann, G.C., McKenzie, J.A., Savin, S. (Eds.), Climate Change in Continental Isotopic Records. American Geophysical Union, Washington, D.C., pp. 217-231. 
530 Cerling, T.E., Wang, Y., Quade, J., 1993, Expansion of $\mathrm{C}_{4}$ ecosystems as an indicator of global 531 ecological change in the late Miocene. Nature 361, 344-345.

532 Cerling, T. E., Harris, J. M., MacFadden, B. J., Leakey, M. G., Quade, J., Eisenmann, V., 533 534

535

536

Ehleringer, J. R., 1997. Global vegetation change through the Miocene/Pliocene boundary. Nature 389, 153-158.

Chamberlain, C.P., Mix, H.T., Mulch, A., Hren, M.T., Kent-Corson, M.L., Davis, S.J., Horton, T.W., Graham, S.A., 2012. The Cenozoic climatic and topographic evolution of the western North American Cordillera. Am. J. Sci. 312, 212-262.

Charreau J., Kent-Corson, M.L., Barrier, L., Augier, R., Ritts, B. D., Chen, Y., France-Lannord, C., Fuilmette, C., 2012. A high-resolution stable isotopic record from the Junggar Basin (NW China): Implications for the paleotopographic evolution of the Tianshan Mountains. Earth Planet Sc. Lett. 341-344, 158-169.

Chen, S. T., and Smith, S.Y., 2013. Phytolith Variability in Zingiberales: A Tool for Reconstruction of Past Tropical Vegetation. Palaeogeogr. Palaeoclimatol. Palaeoecol. $370,1-12$.

Clarke, J., 2003. The occurrence and significance of biogenic opal in the regolith. Earth-Science Rev. 60, 175-194.

Cotton, J.M., 2013. Using soils to constrain past and future terrestrial climate change. $\mathrm{PhD}$ Dissertation, University of Michigan, 278 p.

Cotton, J.M., Hyland, E.G., Sheldon, N.D., 2014. Multi-proxy evidence for tectonic control on the expansion of $\mathrm{C}_{4}$ grasses in northwest Argentina. Earth and Plan. Sci. Let. 395, 41-50. 
Cotton, J. M., Sheldon, N. D., and Strömberg, C.A.E., 2012. High-resolution isotopic record of $\mathrm{C}_{4}$ photosynthesis in a Miocene grassland. Palaeogeogr. Palaeoclimatol. Palaeoecol. 337$338,88-98$.

Diefendorf, A.F., Mueller, K.E., Wing, S.L., Koch, P.L., and Freeman, K.H., 2010. Global patterns in leaf ${ }^{13} \mathrm{C}$ discrimination and implications for studies of past and future climate. PNAS 107, 5738-5743.

Dupont, L.M., Rommerskirchen, F., Mollenhauer, G., Schefuß, E. 2013. Miocene to Pliocene changes in South African hydrology and vegetation in relation to the expansion of $\mathrm{C}_{4}$ plants. Earth Planet. Sci. Lett. 375, 408-417.

Edwards, E.J., Osborne, C.P., Strömberg, C.A.E., Smith, S.A., C 4 Grasses Consortium, 2010. The Origins of $\mathrm{C}_{4}$ Grasslands: Integrating Evolutionary and Ecosystem Science. 328, $587-591$.

Epstein, H.E., Gill, R.A., Paruelo, J.M., Lauenroth, W.K., Jia, G.J., Burke, I.C., 2002. The relative abundance of three plant functional types in temperate grasslands and shrublands of North and South America: effects of projected climate change. J. Biogeogr. 29, 875888.

Feakins, S.J., Levin, N.E., Liddy, H.M., Sieracki, A., Eglinton, T.I., Bonnefille, R. 2013. Northeast African vegetation change over 12 m.y. Geology 41, 295-298.

Ferenac, R.S., Pagnac, D. 2013. Stable carbon isotope evidence for the abundance of $\mathrm{C}_{4}$ plants in the middle Miocene of southern California. Palaeogeogr. Palaeoclimatol. Palaeoecol. 388, $42-47$. 
572 Fraser, D., Theodor, J.M., 2013. Ungulate diets reveal patterns of grassland evolution in North 573 America. Palaeogeogr. Palaeoclimatol. Palaeoecol. 369, 409-421

574

575

576

577

578

579

580

581

582

583

584

585

586

587

588

589

590

591

592

Fredlund, G.G., Tieszen, L.T., 1994. Modern Phytolith Assemblages from the North American Great Plains. J. Biogeogr. 21, 321-335.

Fredlund, G.L.,Tieszen, L.L., 1997. Phytolith and carbon isotope evidence for late Quaternary vegetation and climate change in the southern Black Hills, South Dakota. Quat. Res. 47, 206-217.

Fritz, W.J., Sears, J.W., McDowell, R.J., Wampler, J.M., 2007. Cenozoic volcanic rocks of southwestern Montana. Northwest Geol. 36, 91-110.

Fox, D.L., Koch, P.L., 2003. Tertiary history of $\mathrm{C}_{4}$ biomass in the Great Plains, USA. Geology $31,809-812$.

Fox, D.L., Honey, J.G., Martin, R.A., Peláez-Campomanes, P., 2012. Pedogenic carbonate stable isotope record of environmental change during the Neogene in the southern Great Plains, southwest Kansas, USA: Carbon isotopes and the evolution of $\mathrm{C}_{4}$-dominated grasslands. Geo. Soc. Am. Bull. 124, 444-462.

Garten Jr., C.T., Cooper, L.W., Post III, W.M., Hanson, P.J., 2000. Climate controls on forest soil C isotope ratios in the southern Appalachian Mountains. Ecology 81, 1108-1119.

Gulbranson, E.L., Montañez, I.P., Tabor, N.J., 2011. A proxy for humidity and floral province from paleosols. J. Geol. 119, 559-573.

Hanneman, D.L., Wideman, C.J., 1991. Sequence stratigraphy of Cenozoic continental rocks, southwestern Montana. Geo. Soc. Am. Bull. 103, 1335-1345. 
Hanneman, D.L., Wideman, C.J., 2006. Calcic pedocomplexes - regional sequence boundary indicators in Tertiary deposits of the Great Plains and western United States. GSA Spec. Paper 416, 1-15.

Hamer, J.M.M., 2009. Interpreting Cenozoic floodplains: a paleopedological and ichnological perspective. PhD Dissertation, Royal Holloway, 462 p.

Hamer, J.M.M., Sheldon, N.D., Nichols, G.J., Collinson, M.E., 2007. Late Oligocene-Early Miocene paleosols of distal fluvial systems, Ebro Basin, Spain. Palaeogeography, Palaeoclimatology, Palaeoecology 247, 220-235.

Hasiotis, S.T., 2004. Reconnaissance of Upper Jurassic Morrison Formation ichnofossils, Rocky Mountain Region, USA: paleoenvironmental, stratigraphic, and paleoclimatic significance of terrestrial and freshwater ichnocoenoses. Sediment. Geol. 167, 117-268.

Huang, Y., Clemens, S.C., Liu, W., Wang, Y., Prell, W.L. 2007. Large-scaled hydrological change drove the late Miocene $\mathrm{C}_{4}$ plant expansion in the Himalayan foreland and Arabian Peninsula. Geology 35, 531-534.

Hui, Z., Li, J., Xu, Q., Song, C., Zhang, J., Wu, F., Zhao, Z. 2011. Miocene vegetation and climatic changes reconstructed from a sporopollen record of the Tianshui Basin, NE Tibetan Plateau. Palaeogeogr. Palaeoclimatol. Palaeoecol. 308, 373-382.

Hyland, E.H., Smith, S.Y., Sheldon, N.D., 2013. Representational bias in phytoliths from modern soils of central North America: Implications for paleovegetation reconstructions. Palaeogeogr. Palaeoclimatol. Palaeoecol. 374, 338-348. 
613 Hynek, S., Passey, B.H., Prado, J.L., Brown, F.H., Cerling, T.E., Quade, J. 2012. Small mammal 614 carbon isotope ecology across the Miocene-Pliocene boundary, northwestern Argentina. Earth Planet. Sc. Lett. 321-322, 177-188.

616

617

618

619

620

621

622

623

624

625

626

627

628

629

630

631

Ingram, A.L., Christin, P.A., Osborne, C.P., 2011. Molecular phylogenies disprove a hypothesized $\mathrm{C}_{4}$ reversion in Eragrostis walteri (Poaceae). Ann. Botany 107, 321-325.

Jacobs, B.F., Kingston, J.D., Jacobs, L.L., 1999. The origin of grass-dominated ecosystems. Ann. Miss. Bot. Gard. 86, 590-643.

Janis, C.M., Damuth, J., Theodor, J.M., 2000. Miocene ungulates and terrestrial primary productivity: Where have all the browsers gone?. Proc. Natl. Acad. Sci. 97, 7899-7904.

Jia, G., Li, Z., Peng, P., Zhou, L., 2012. Aeolian n-alkane isotopic evidence from North Pacific for a Late Miocene decline of $\mathrm{C}_{4}$ plant in the arid Asian interior. Earth Planet. Sc. Lett. $321-322,32-40$.

Kohn, M.J., 2010. Carbon isotope compositions of terrestrial $C_{3}$ plants as indicators of (paleo)ecology and (paleo)climate. PNAS 107, 19691-19695.

Larsson, L.M., Dybkjaer, K., Rasmussen, E.S., Piasecki, S., Utescher, T., Vajda, V. 2011. Miocene climate evolution of northern Europe: A palynological investigation from Denmark. Palaeogeog. Palaeoclimat. Palaeoecol. 309, 161-175.

Lehmann, C.E.R., Archibald, S.A., Hoffmann, W.A., Bond, W.J., 2011. Deciphering the distribution of the savanna biome. New Phyt. 191, 197-209. 
632 Leier, A., Quade, J., Decelles, P., Kapp, P., 2009. Stable isotopic results from paleosol carbonate 633 in South Asia: Paleoenvironmental reconstructions and selective alteration. Earth Planet 634 Sc. Lett. 279, 242-254.

635 Leopold, E.B., MacGinitie, H.D., 1972. Development and affinities of Tertiary floras in the 636 Rocky Mountains, in, Graham, A. (ed.), Floristics and Paleofloristics of Asia and Eastern 637 Li, J., Wang, G., Liu, X., Han, J., Liu, M., Liu, X., 2009. Variations in carbon isotope 638 ratios of $\mathrm{C} 3$ plants and distribution of $\mathrm{C}_{4}$ plants along an altitudinal transect on the 639 eastern slope of Mount Gongga. Sci. China D: Ear. Sci. 52, 1714-1723.

640

641

642

643

644

645

646

647

648

649

650
Lielke, K., Manchester, S., Meyer, H., 2012. Reconstructing the environment of the northern Rocky Mountains during the Eocene/Oligocene transition: constraints from the palaeobotany and geology of south-western Montana, USA. Acta Palaeobotanica 52, 317-358.

Liu, H., Edwards, E.J., Freckleton, R.P., Osborne, C.P. 2012. Phylogenetic niche conservatism in $\mathrm{C}_{4}$ grasses. Oecologia 170:835-845.

Martin, C., Bentaleb, I., Antoine, P.O., 2011. Pakistan mammal tooth stable isotopes show paleoclimatic and paleoenvironmental changes since the early Oligocene. Palaeogeogr. Palaeoclimatol. Palaeoecol. 311, 19-29.

Masrahi, Y.S., Al-Turki, T.A., Sayed, O.H., 2012. Geographic distribution and chorology of grasses in the Arabian Peninsula. Flora - Morph., Dist. Func. Eco Plants 207, 250-256. 
McInerney, F.A., Strömberg, C.A.E., White, J.W.C., 2011. The Neogene transition from $\mathrm{C}_{3}$ to $\mathrm{C}_{4}$ grasslands in North America: stable carbon isotope ratios of fossil phytoliths. Paleobiology 37, 23-49.

Miller, L.A., Smith, S.Y., Sheldon, N.D., Strömberg, C.A.E., 2012. Eocene vegetation dynamics inferred from a high-resolution phytolith record. Geol. Soc. Am. Bull. 124, 1577-1589.

Osborne, C.P., 2008. Atmosphere, ecology and evolution: what drove the Miocene expansion of $\mathrm{C}_{4}$ grasslands? J. Ecology 96, 35- 45.

Pagani, M., Freeman, K. H., Arthur, M. A. 1999. Late Miocene atmospheric $\mathrm{CO}_{2}$ concentrations and the expansion of $\mathrm{C}_{4}$ grasses. Science $285,876-879$.

Passey, B.H., Cerling, T.E., Perkins, M.E., Voorhies, M.R., Harris, J.M., Tucker, S.T. 2002. Environmental change in the Great Plains: an isotopic record from fossil horses. J. Geol. $110,123-140$.

Piperno, D.R., 1985. Phytolith Analysis and Tropical Paleo-ecology: Production and Taxonomic Significance of Siliceous Forms in New World Plant Domesticates and Wild Species. Rev. Paleobot. Palyno. 45, 185-228.

Piperno, D.R., 1988. Phytolith Analysis, an Archaeological and Geological Perspective. Academic Press, San Diego.

Piperno, D.R., 1989. The occurrence of phytoliths in the reproductive structures of selected tropical angiosperms and their significance in tropical paleoecology, paleoethnobotany and systematics. Rev. Pal. Pal. 61, 147-173. 
671 Piperno, D.R., 2006. Phytoliths: A Comprehensive Guide for Archaeologists and Paleoecologists.

$672 \quad$ AltaMira Press, Plymouth, 304 p.

673 Prasad, V., Strömberg, C. A. E., Alimohammadian, H., and Sahni, A. 2005. Dinosaur Coprolites 674 and the Early Evolution of Grasses and Grazers. Science 310:1177-1180.

675 Prychid, C.J., Rudall, P.J., and Gregory, M., 2004. Systematics and Biology of Silica Bodies in 676 Monocotyledons. Bot. Rev. 69, 377-440.

677 Retallack, G.J., 2007. Cenozoic paleoclimate on land in North America. J. Geol. 115, 271-294.

678 Sage, R.F., 2004. The evolution of $\mathrm{C}_{4}$ photosynthesis. New Phytol. 161, 341-370.

679 Sage, R.F., Christin, P.-A., Edwards, E.J. 2011. The $\mathrm{C}_{4}$ plant lineages of planet Earth. J. Exp. Bot. $680 \quad 62,3155-3169$.

681 Scheiter, S., Higgins, S. I., Osborne, C.P., Bradshaw, C., Lunt, D., Ripley, B.S., Taylor, L.L., and 682 Beerling, D.J., 2012. Fire and fire-adapted vegetation promoted $\mathrm{C}_{4}$ expansion in the late 683 Miocene. New Phytol. 195, 653-666.

684 Sheldon, N.D., Tabor, N.J., 2009. Quantitative paleoenvironmental and paleoclimatic 685 reconstruction using paleosols. Earth-Science Reviews 95, 1-52.

686 Sheldon, N. D., Retallack, G. J., Tanaka, S., 2002. Geochemical climofunctions from North 687 American soils and application to paleosols across the Eocene-Oligocene boundary in 688 Oregon. J. Geol. 110, 687-696. 
Singh, S., Awasthi, A.K., Parkash, B., and Kumar, S., 2013. Tectonics or climate: What drove the Miocene global expansion of $\mathrm{C}_{4}$ grasslands?. Int. J. Earth Sci., DOI 10.1007/s00531013-0893-5

Smith, S.Y., Collinson, M.E., Rudall, P.J., Simpson, D.A., 2010. The Cretaceous and Paleogene fossil record of Poales: review and current research. In: Seberg. O., Petersen, G., Barfod, A., Davis, J.I., eds. Diversity, Phylogeny, and Evolution in Monocotyledons: Proceedings of the Fourth International Conference on the Comparative Biology of the Monocotyledons \& the Fifth International Symposium on Grass Systematics and Evolution. Aarhus University Press, Aarhus, p. 333-356.

Strömberg, C A.E., 2002. The origin and spread of grass-dominated ecosystems in the late Tertiary of North America: preliminary results concerning the evolution of hypsodonty. Palaeogeogr. Palaeoclimatol. Palaeoecol. 177, 59-75.

Strömberg, C.A.E., 2003. The origin and spread of grass-dominated ecosystems during the Tertiary of North America and how it relates to the evolution of hyposodonotry in equids. Ph.D. thesis, UC Berkeley 779 p.

Strömberg, C.A.E., 2004. Using phytolith assemblages to reconstruct the origin and spread of grass-dominated habitats in the great plains of North America during the late Eocene to early Miocene. Palaeogeogr. Palaeoclimatol. Palaeoecol. 207, 239-275.

Strömberg, C.A.E., 2005. Decoupled taxonomic radiation and ecological expansion of openhabitat grasses I the Cenozoic of North America. PNAS 102, 11980-11984. 
709

710

711

712

713

714

715

716

717

718

719

720

721

722

723

724

725

726

727

Strömberg, C.A.E., 2009. Methodological concerns for analysis of phytolith assemblages: Does count size matter? Quat. Int.193, 124-140.

Strömberg, C.A.E., 2011. The origin and spread of grass-dominated habitats. Annu. Rev. Earth Planet Sci. 39, 517-544.

Strömberg, C.A.E., McInerney, F.A., 2011. The Neogene transition from $\mathrm{C}_{3}$ to $\mathrm{C}_{4}$ grasslands in North America: assemblage analysis of fossil phytoliths. Paleobiogy 37, 50-71.

Strömberg, C.A.E., Dunn, R.E., Madden, R.H., Kohn, M.J., Carlini, A.,A., 2013. Decoupling the spread of grasslands from the evolution of grazer-type herbivores in South America. Nature Communications 4, 1-8.

Tabor, N.J., Myers, T.S., Gulbranson, E., Rasmussen, C., Sheldon, N.D. 2013. Carbon stable isotope composition of modern calcareous soil profiles in California: implications for $\mathrm{CO}_{2}$ reconstructions from calcareous paleosols, in, Driese, S.G. and Nordt, L. (Eds.), New Frontiers in Paleopedology and Terrestrial Paleoclimatology, SEPM Special Paper No. 104, p. $17-34$.

Taft, J.B., Phillippe, L.R., Dietrich, C.H., Robertson, K.R. 2011. Grassland composition, structure, and diversity patterns along major environmental gradients in the Central Tien Shan. Plant Ecol. 212:, 1349-1361.

Taub, D. R., 2000. Climate and the U.S. distribution of $\mathrm{C}_{4}$ grass subfamilies and decarboxylation variants of $\mathrm{C}_{4}$ photosynthesis. Am. J. Bot. 87, 1211-1215. 
728

729

730

731

732

733

734

735

736

737

738

739

740

741

742

743

744

745

746

747

748

Tipple, B. J., Meyers, S. R., Pagani, M., 2010. Carbon isotope ratio of Cenozoic $\mathrm{CO}_{2}$ : A comparative evaluation of available geochemical proxies. Paleoceanography 25, doi:10.1029/2009PA001851.

Tipple, B. J., Pagani, M., 2010. A 35 Myr North American leaf-wax compound-specific carbon and hydrogen isotope record: Implications for $\mathrm{C}_{4}$ grasslands and hydrologic cycle dynamics. Earth Planet Sc. Lett. 299, 250-262.

Uno, K.T., Cerling, T.E., Harris, J.M., Kunimatsu, Y., Leakey, M.G., Nakatsukasa, M., Nakaya, H. 2011. Late Miocene to Pliocene carbon isotope record of differential diet change among East African herbivores. Proc. Nat. Acad. Sci. 108, 6509-6514.

Urban, M.A., Nelson, D.M., Jiménez-Moreno, G., Châteauneu, J., Pearson, A., Hu, F.S. 2010. Isotopic evidence of $\mathrm{C}_{4}$ grasses in southwestern Europe during the Early OligoceneMiddle Miocene. Geology 38,1091-1094.

Van de Water, P.K., Leavitt, S.W., Betancourt, J.L., 2002. Leaf $\delta^{13}$ C variability with elevation, slope aspect, and precipitation in the Southwest United States. Oecologia 132, 332-343.

Wynn, J.G., 2007. Carbon isotope fractionation during decomposition of organic matter in soils and paleosols: implications for paleoecological interpretations of paleosols. Palaeogeography, Palaeoclimatology, Palaeoecology 251, 437-448.

Wynn, J.G., Bird, M.I., 2007. C4-derived soil organic carbon decomposes faster than its C3 counterpart in mixed C3/C4 soils. Global Change Biology 13, 2206-2217.

Wynn, J.G., Bird, M.I., Wong, V.N.L., 2005. Rayleigh distillation and the depth profile of ${ }^{13} \mathrm{C} /{ }^{12} \mathrm{C}$ ratios of soil organic carbon from soils of disparate texture in Iron Range 

National Park, Far North Queensland, Australia. Geochim. Cosmochim. Acta 69, 1961-

750 1973.

751

752

753

754

755

756

757

758

759

760

761

762

763

764

Zin-Maung-Maung-Thein, Takai, M., Uno, H., Wynn, J.G., Egi, N., Tsubamota, T., ThaungHtike, Aung-Naing-Soe, Maung-Maung, Nishimura, T., Yoneda, M. 2011. Stable isotope analysis of the tooth enamel of Chaingzauk mammalian fauna (late Neogene, Myanmar) and its implication to paleoenvironment and paleogeography. Palaeogeog. Palaeoclimatol. Palaeoecol. 300, 11-22.

Zhang, C., Wang, Y., Deng, T., Wang, X., Biasatti, D., Xu, Y., Li, Q., 2009. C 4 expansion in the central Inner Mongolia during the latest Miocene and early Pliocene. Earth Planet Sc. Lett. 287, 311-319.

Zhang, C., Wang, Y., Wang, X., Deng, T., Tseng, Z. J., Takeuchi, G. T., Xie, G., et al., 2012. Diets and environments of late Cenozoic mammals in the Qaidam Basin, Tibetan Plateau: Evidence from stable isotopes. Earth Planet Sc. Lett. 333-334, 72-80.

Zhang, Y.G., Pagani, M., Liu, Z., Bohaty, S.M., DeConto, R., 2013. A 40-million-year history of atmospheric $\mathrm{CO}_{2}$. Phil. Trans. Roy. Soc. A, doi: 10.1098/rsta.2013.0096. 


\section{Captions}

766

767 Figure 1. Map showing location of sampling site and of a penecontemporaneous site from

768 Cotton et al. (2012). Modified from Miller et al. (2012).

769 Figure 2. Examples of trace fossils found on site. A, Back-filled burrows. B, Downward

770 branching burrows, organic root traces (dark). C, Calcified roots, with preserved cortical cells. D,

771 Ant nest trace fossil (e.g., Hasiotis, 2004; Hamer et al., 2007).

772 Figure 3. Stratigraphic column showing sampling levels and phytolith assemblage, isotopic

773 value, and corresponding percent $\mathrm{C}_{4}$ estimate for each method. Stars represent horizons sampled

774 for organic matter $\delta^{13} \mathrm{C}$ analysis and pie charts correspond to phytolith samples with good yields.

775 Sampling horizons with isotopic results but not pie chart correspond to samples with poor

776 phytolith yields. Error bars (for isotopic value): $\pm 1 \sigma$ based on $\delta^{13} \mathrm{C}_{\text {atm }}$ uncertainty (Tipple et al.,

777 2010). Ninety-five percent confidence intervals (for phytoliths) derived through bootstrapping in

778 R (R Development Core Team 2013). Small symbols denote error/confidence intervals.

779 Phytolith-isotope sample offsets are for readability purposes; they are derived from the same

780 samples and horizons. For A horizon samples from lower paleosol, the error range is averaged

781 from all three samples.

782 Figure 4. Microphotographs of selected biosilica. A-C, diatoms. D, sponge spicule. E, F, algal

783

cyst. G, Elo-1: Smooth elongate (OTH). H, Epi-9: Spiny elongate (GRASS/MONO-ND). I, Tri-8:

784 Trichome filling (GRASS/MONO-ND). J, Blo-2: Thickened rectangular plate (OTH). K, Cl-11:

785 Small, grainy sphere (OTH). L, Cl-7: Small rugulose sphere and subsphere (FI-GEN). M, M-8:

786 Solid parenchyma cell (OTH). N, Clm-2a: Echinate (spiky) sphere (PALM-D). O, Kn-1: M-8

787 with knobs (OTH). P, CE-1: Crenate with symmetry A (POOID-D). Q, CE-1: Crenate with 
symmetry A (POOID-D), lateral view. R, BI-2: Bilobate with rounded top (POOID-D). S, BI-1: Regular Stipa type bilobate (POOID-D). T, KR-1: Regular keeled rondel (POOID-ND). U, CO-1: Generic (truncated) conical rondel (POOID-ND). V, BI-7: Symmetry D bilobate (PACMAD791 GEN). W, CR3-1: 3-lobe cross with cross-shape top (PANI), lateral view. X, CR3-2: 3-lobe 792 cross with near cross-shape top (PANI). Y, CR4-2: 4-lobed cross with near cross-shaped top 793 (PANI). Scale bar: $5 \mu \mathrm{m}$.

Figure 5. Sample-to-sample comparison of paleosol organic carbon isotope and phytolith 795 assemblage $\mathrm{C}_{4}$ percentage estimates, including data from Cotton et al., (2012). Error bars (for 796 isotopic value; in black): $\pm 1 \sigma$ based on $\delta^{13} \mathrm{C}_{\text {atm }}$ uncertainty (Tipple et al., 2010) for this study, $797 \pm 1 \sigma$ based on replication for Cotton et al., (2012). Ninety-five percent confidence intervals (for 798 phytoliths; in grey) derived through bootstrapping in R (R Development Core Team 2013).

Figure 6. Comparison of percent grass and maximum percent $\mathrm{C}_{4}$ estimated from phytolith and $\mathrm{C}$ 800 isotope data for Montana and the Great Plains from 16-8 Ma. Montana C isotope data derived 801 from paleosol organic matter (this paper; Cotton et al., 2012; Miller et al., 2012); Great Plains 802 data plotted as running average from paleosol carbonates (two-point running average; Fox and 803 Koch, 2003) and phytolith data (four-point running average; Strömberg, 2005; Strömberg and 804 McInerny, 2011). Note that maximum phytolith estimates for $\mathrm{C}_{4}$ in the central Great Plains are 805 much lower than paleosol carbonate data estimates, whereas soil organic matter and phytoliths 806 agrees well in Montana.

807 Table 1. Percent $\mathrm{C}_{4}$ estimates and vegetation interpretations from other late Miocene sites. Data 808 presented are in addition to those compiled by Edwards et al. (2010). Ecosystems were described 809 as $\mathrm{C}_{3}$-dominant unless additional evidence (e.g. phytoliths or pollen) existed about openness. 
$810{ }^{a}$ Pedogenic carbonates have been found to bias towards $\mathrm{C}_{4}$ composition, potentially due to 811 diagenesis or diffusion of atmospheric $\mathrm{CO}_{2}$ (see Cotton et al. (2012) for discussion). ${ }^{\mathrm{b}}$ Isotopes in 812 phytoliths from grass-dominated habitats measure mainly the isotopic signal of the grass

813 community rather than of overall vegetation, hence these values are higher than isotopic analyses 814 of, for example, bulk organic material (see McInerney et al. (2011) for discussion). 
FigureV

Figure 1

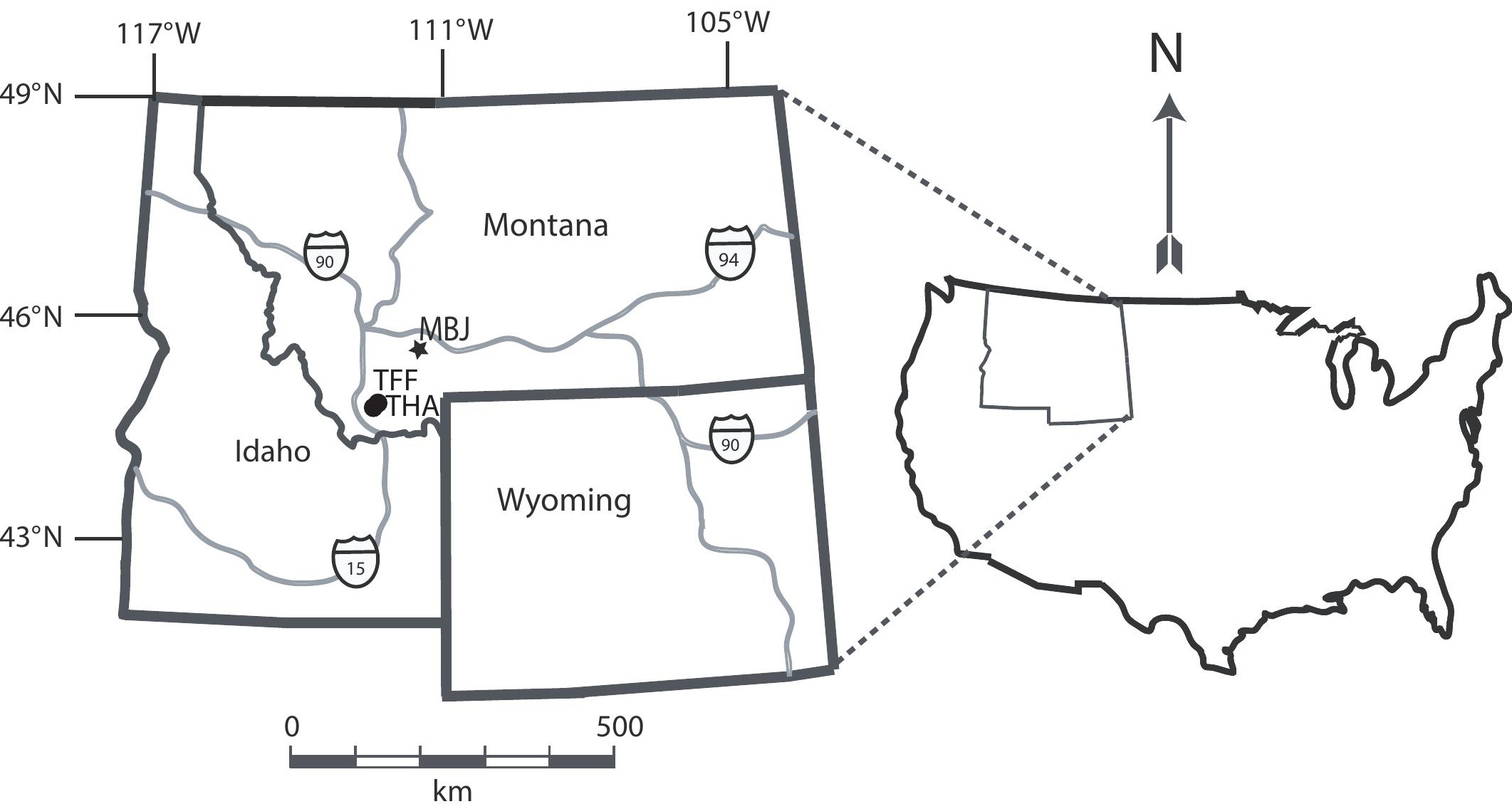




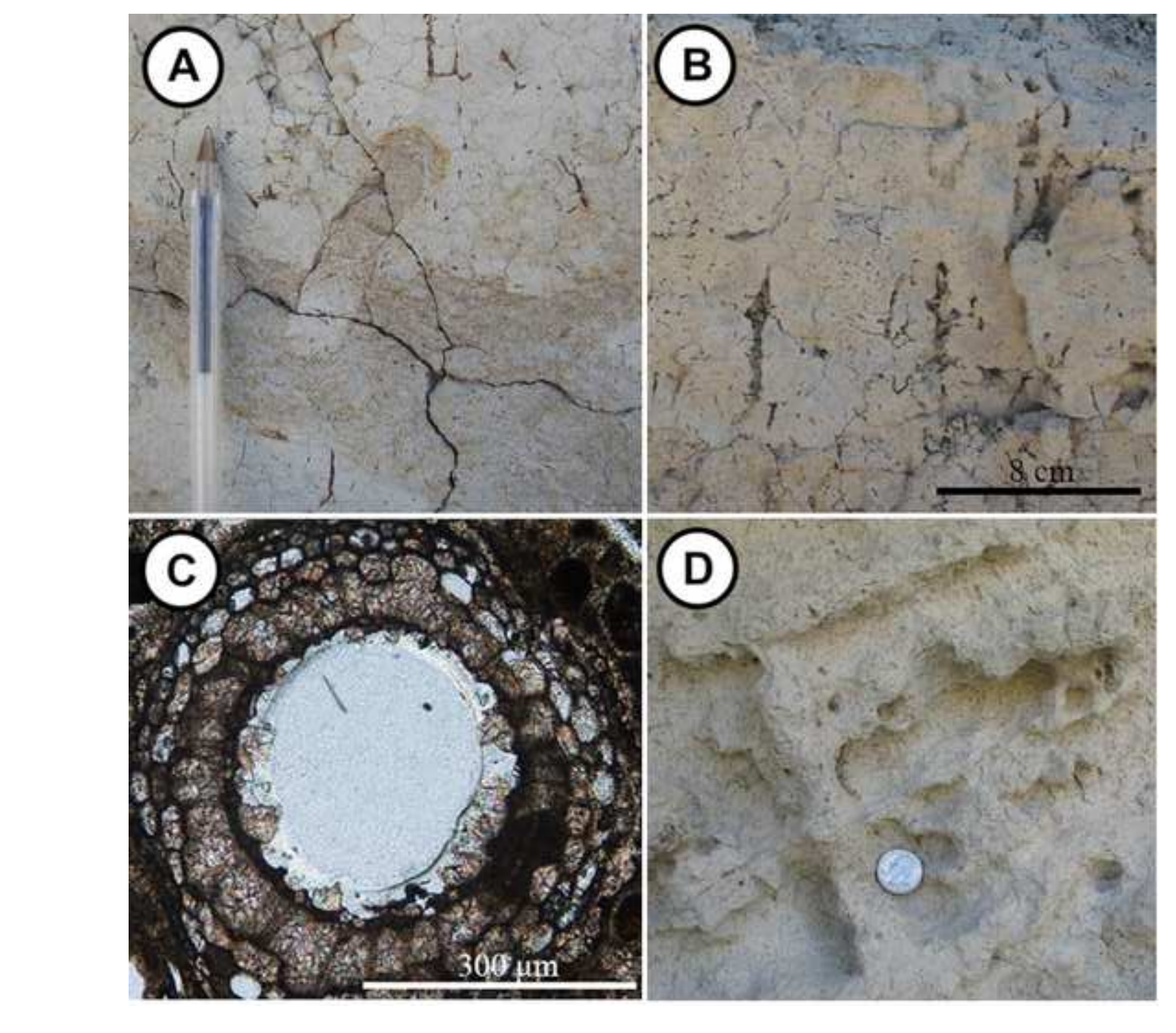



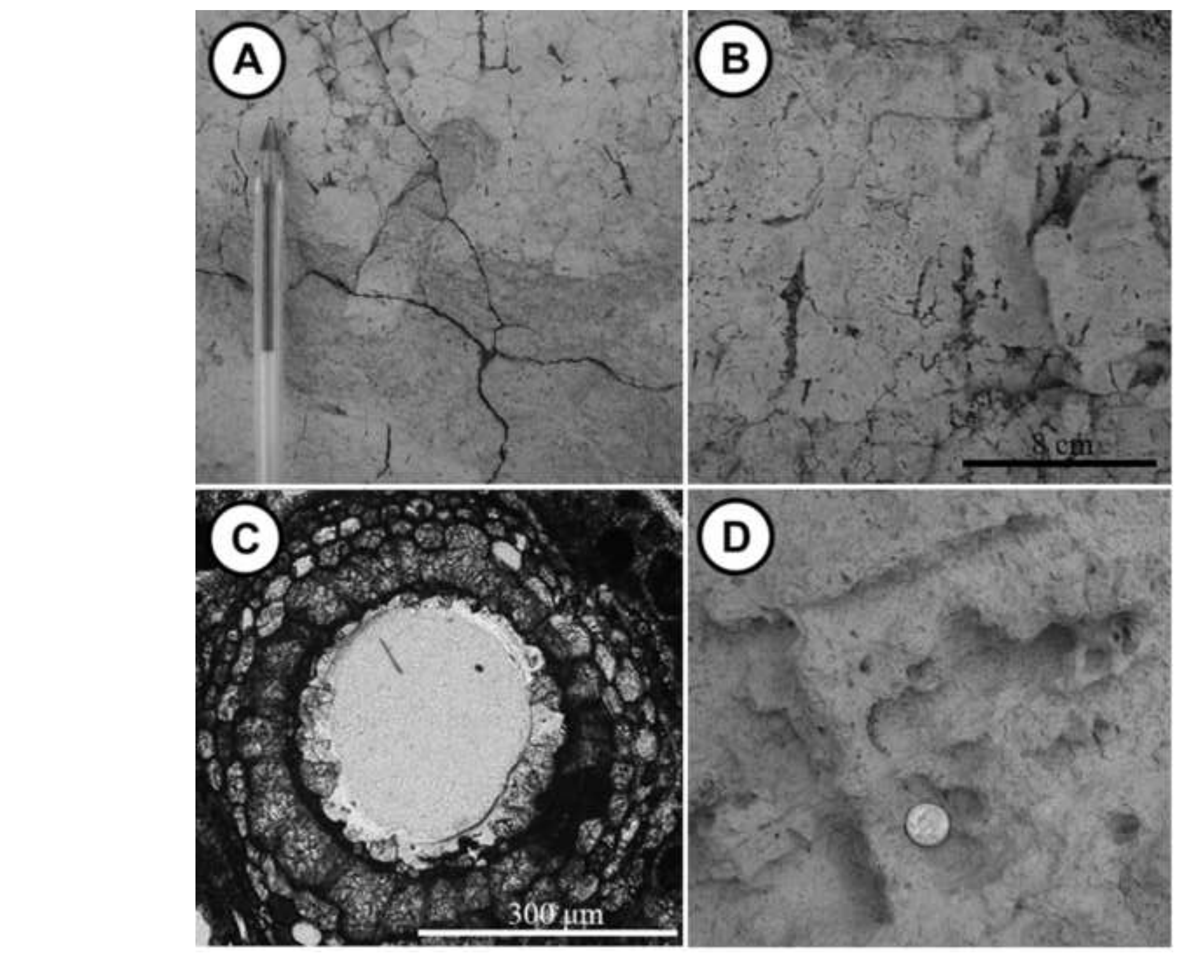

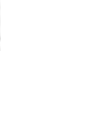

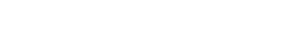

.

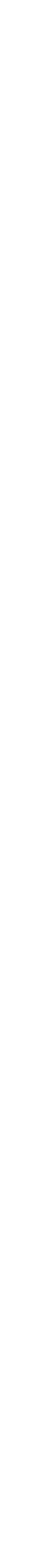




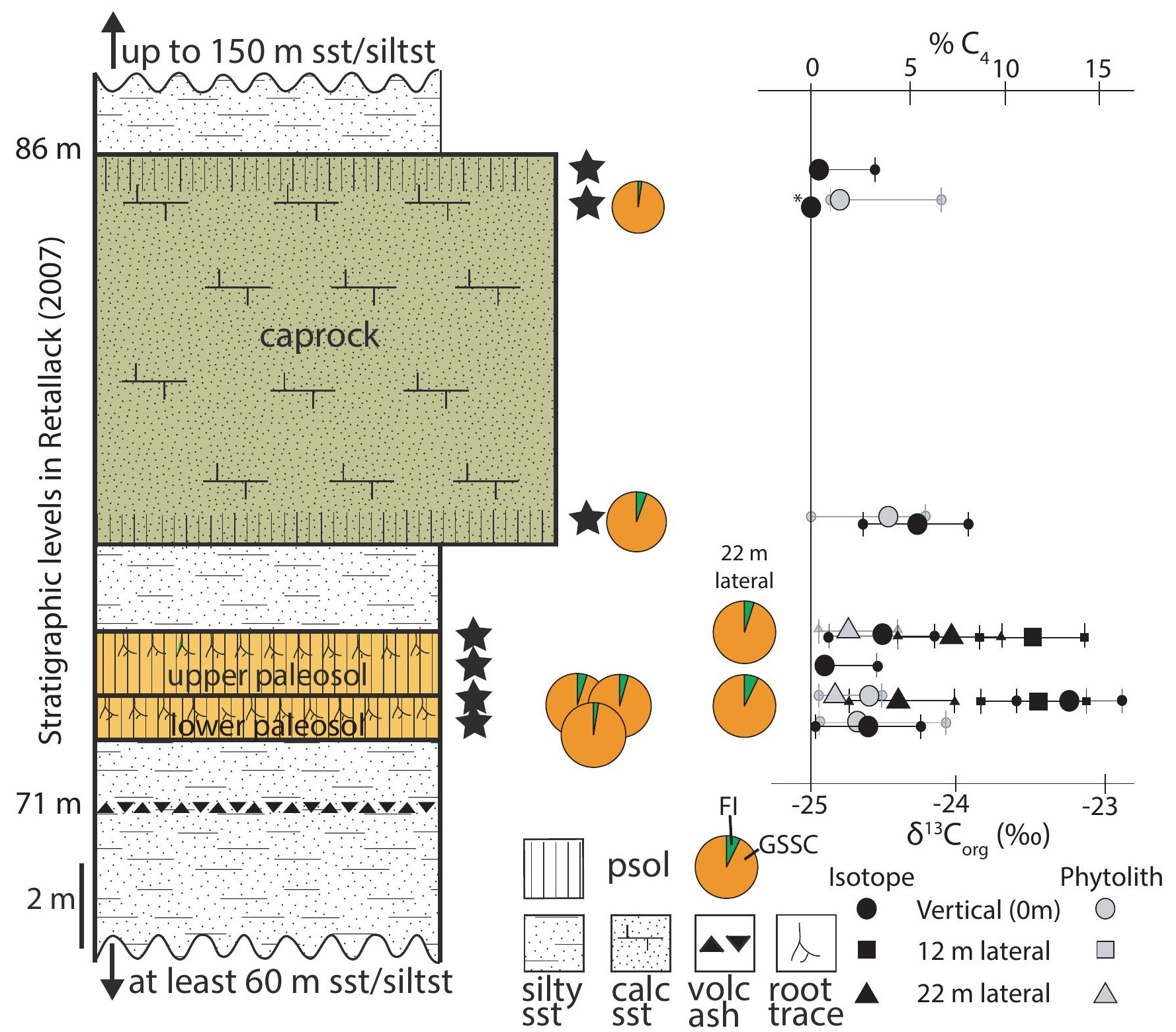




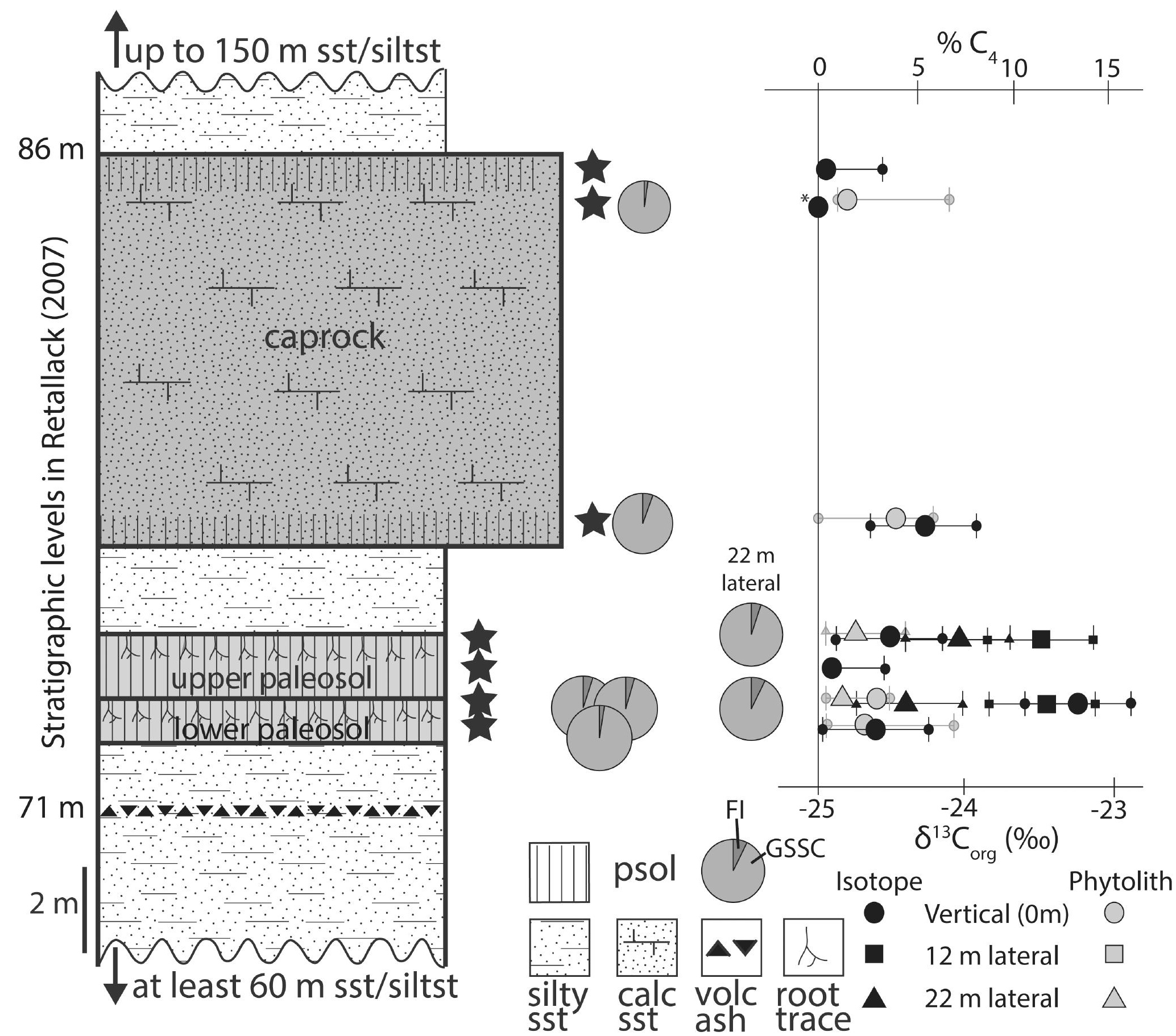



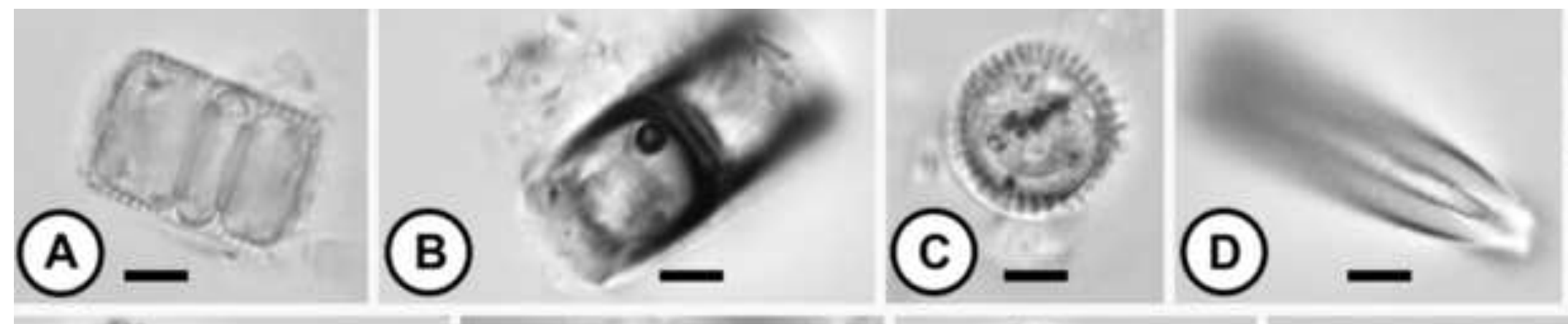

(E) $-\frac{1}{0}$
(F) -
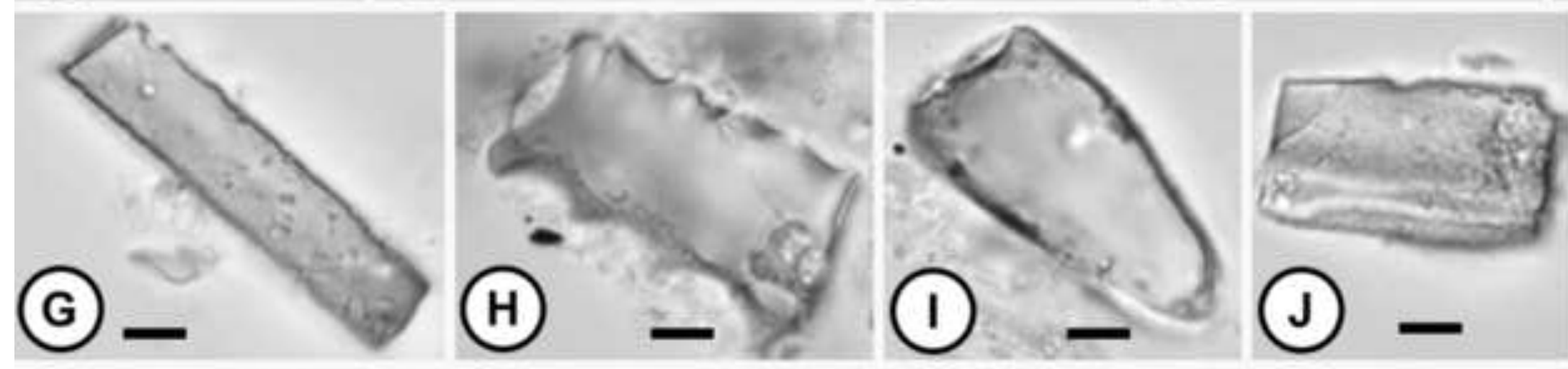

() -

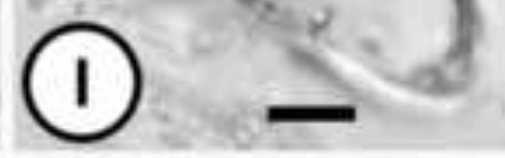

(1) -

(L) -
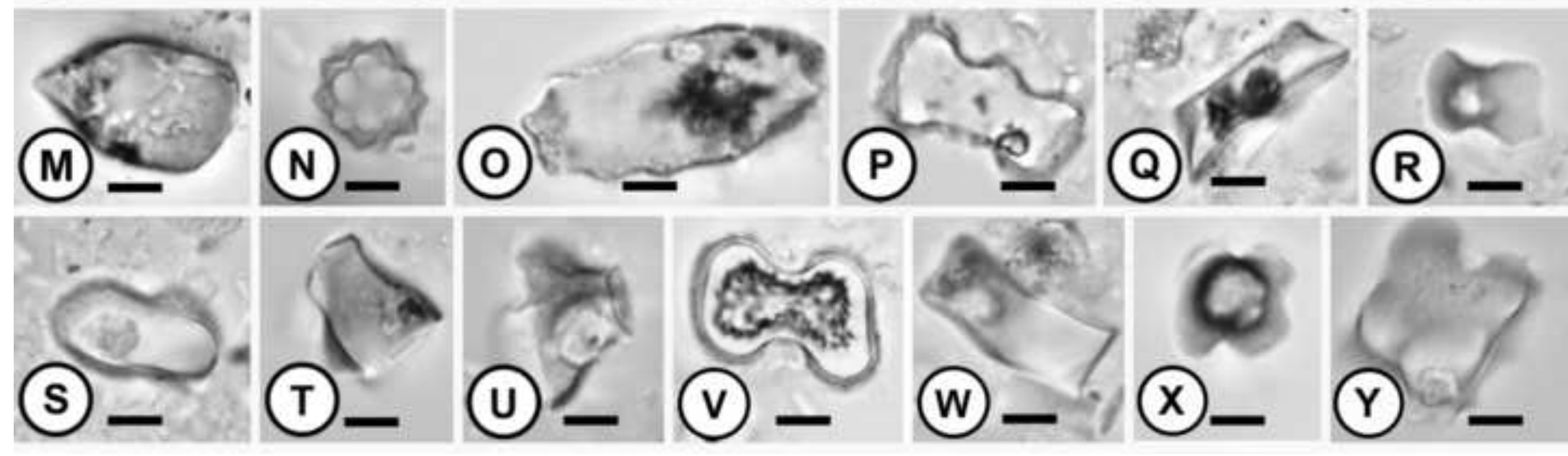


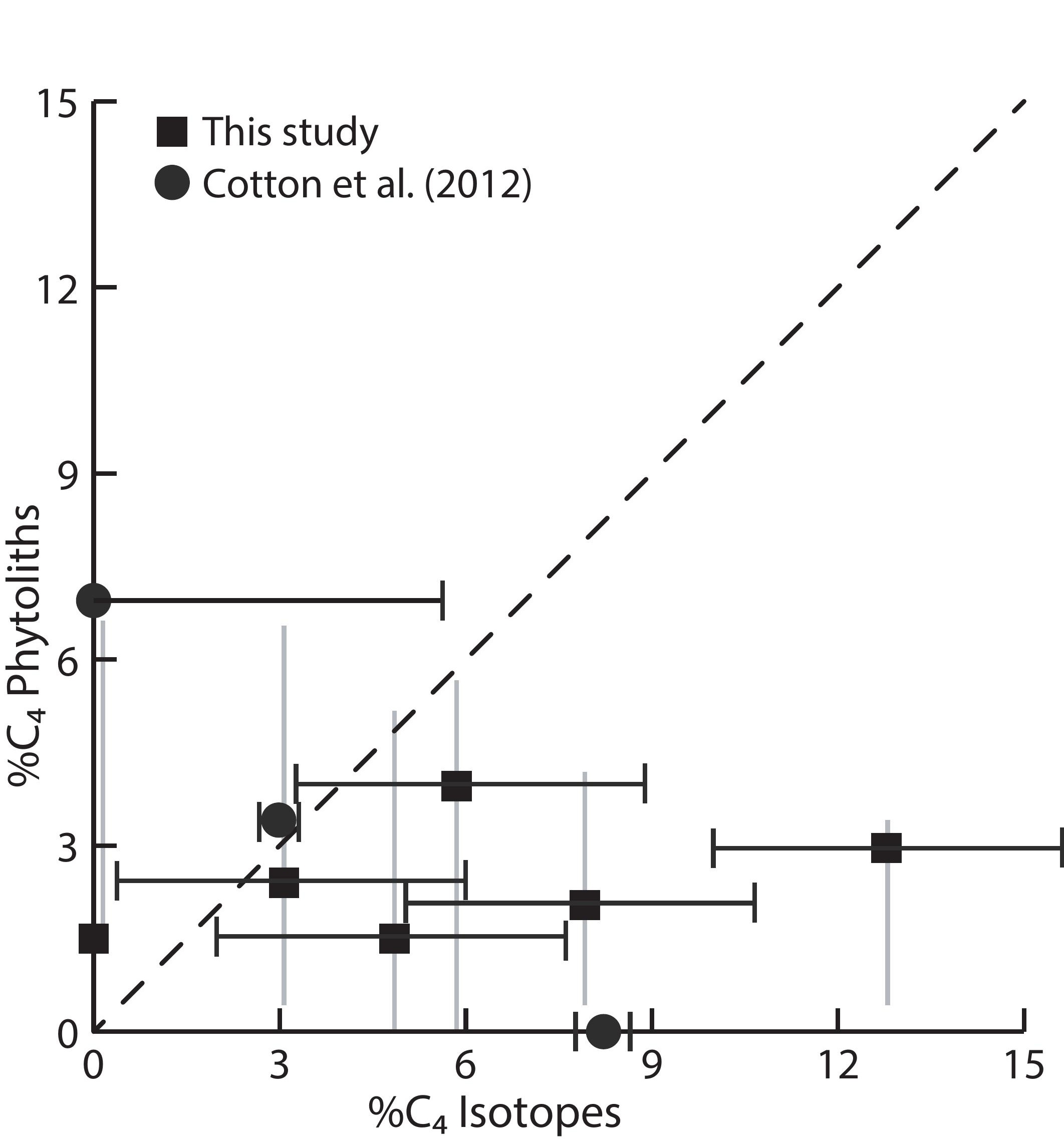

Figure 5 
Figure 6

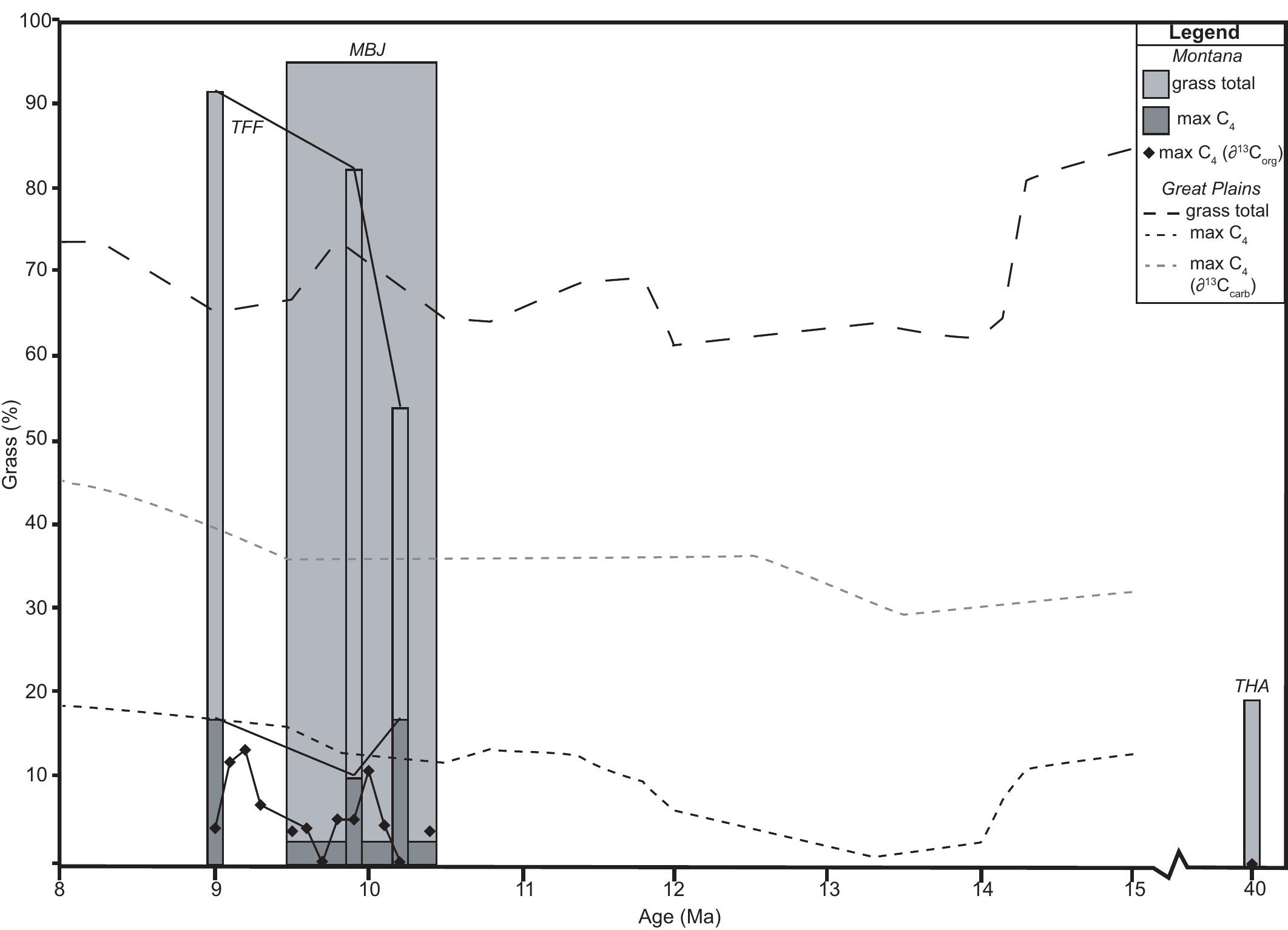




\section{TableV}

Table 1

\begin{tabular}{|c|c|c|c|c|c|c|}
\hline Location & Time & $\delta^{13} \mathrm{C}(\%)$ & $\% \mathbf{C}_{4}$ & $\begin{array}{c}\text { Inferred } \\
\text { Ecosystem }\end{array}$ & Proxy & Source \\
\hline \multicolumn{7}{|l|}{ North America } \\
\hline \multirow{5}{*}{$\begin{array}{c}\text { Kansas + Nebraska, } \\
\text { USA }\end{array}$} & $\begin{array}{l}11.2-9.5 \\
\mathrm{Ma}\end{array}$ & $-24.3(-25.8$ to -23.2$)$ & $0-15 \%$ & $\mathrm{C}_{3}$-grassland & $\begin{array}{l}\text { Soil isotopes and } \\
\text { phytoliths }\end{array}$ & This paper \\
\hline & $\begin{array}{l}10.2-8.9 \\
\mathrm{Ma}\end{array}$ & $-23.9(-26.5$ to 19.9$)$ & $0-25 \%$ & $\mathrm{C}_{3}$-grassland & $\begin{array}{l}\text { Soil isotopes and } \\
\text { phytoliths }\end{array}$ & Cotton et al. (2012) \\
\hline & $39.2 \mathrm{Ma}$ & -25.1 to -21.8 & $0 \%$ & $\mathrm{C}_{3}$-forest & Phytoliths & Miller et al. (2012) \\
\hline & $12-2 \mathrm{Ma}$ & -27 to -15 & $\begin{array}{c}0- \\
100 \%\end{array}$ & $\mathrm{C}_{3}$-grassland & $\begin{array}{l}\text { Carbon isotopes from } \\
\text { phytoliths }\end{array}$ & Mclnerney et al. (2011) \\
\hline & $12-2 \mathrm{Ma}$ & $\mathrm{n} / \mathrm{a}$ & $0-60 \%$ & $\mathrm{C}_{3}$-grassland & Phytoliths & $\begin{array}{l}\text { Strömberg and Mclnerney } \\
\text { (2011) }\end{array}$ \\
\hline Kansas, USA & $\begin{array}{l}25 \mathrm{Ma}- \\
\text { present }\end{array}$ & -8.7 to 0.9 & $\begin{array}{l}10- \\
78 \%\end{array}$ & $\mathrm{C}_{3}$-dominant & Carbonate isotopes & Fox et al. (2012) \\
\hline Great Plains & $\begin{array}{l}35 \mathrm{Ma}- \\
\text { present }\end{array}$ & $\begin{array}{c}-30 \text { to }-28\left(n-C_{29}\right) \text { and }-30 \text { to }-24 \\
\left(n-C_{31}\right)\end{array}$ & $\begin{array}{l}20- \\
50 \%\end{array}$ & $\mathrm{C}_{3}$-dominant & Leaf wax isotopes & Tipple and Pagani (2010) \\
\hline \multicolumn{7}{|l|}{ South America } \\
\hline \multirow[t]{3}{*}{ Argentina } & $40-18 \mathrm{Ma}$ & $\mathrm{n} / \mathrm{a}$ & $0 \%$ & $\mathrm{C}_{3}$-forest & \multirow{4}{*}{$\begin{array}{c}\text { Phytoliths } \\
\text { Enamel isotopes } \\
\text { Soil isotopes and } \\
\text { phytoliths }\end{array}$} & Strömberg et al. (2013) \\
\hline & $9-3.5 \mathrm{Ma}$ & -14 to 4 & $0-80 \%$ & $\mathrm{C}_{3}$-dominant & & Hynek et al. (2012) \\
\hline & $6.2-3.3$ & $-24.6(-27.5$ to -22.3$)$ & $0 \%$ & $\mathrm{C}_{3}$-dominant & & Cotton et al. (2014) \\
\hline \multicolumn{6}{|l|}{ Asia } & \\
\hline \multirow[t]{5}{*}{ Tibetan Plateau } & $\begin{array}{l}14 \mathrm{Ma}- \\
\text { present }\end{array}$ & -12 to -4 & $0-30 \%$ & $\mathrm{C}_{3}$-dominant & Enamel isotopes & Zhang et al. (2012) \\
\hline & $\begin{array}{l}16 \mathrm{Ma}- \\
\text { present }\end{array}$ & -25 to -21 & $\begin{array}{l}10- \\
20 \%\end{array}$ & $\mathrm{C}_{3}$-dominant & Leaf wax isotopes & Jia et al. (2012) \\
\hline & $50-15 \mathrm{Ma}$ & -11 to -2 & $0 \%$ & $\mathrm{C}_{3}$-dominant & Carbonate isotopes & Leier et al. (2009) \\
\hline & 23.6-1 Ma & -12.9 to 3 & $0 \%$ & $\begin{array}{c}\mathrm{C}_{3} \text { dominant } \\
\text { Forest (until } 147\end{array}$ & Carbonate isotopes & Charreau et al. (2012) \\
\hline & $\begin{array}{c}17.1-6.1 \\
\mathrm{Ma}\end{array}$ & $\mathrm{n} / \mathrm{a}$ & - & $\begin{array}{c}\text { Ma), Forest- } \\
\text { steppe (14.7-11. } \\
\text { Ma), Steppe } \\
\text { (after } 8.5 \mathrm{Ma})\end{array}$ & Pollen & Hui et al. (2011) \\
\hline \multirow[t]{2}{*}{ Pakistan } & $\begin{array}{l}14 \mathrm{Ma}- \\
\text { present }\end{array}$ & -12 to 3 & $\begin{array}{l}0- \\
100 \%\end{array}$ & $\mathrm{C}_{3}$-dominant & Carbonate isotopes & Singh et al. (2013) \\
\hline & $30-7.5 \mathrm{Ma}$ & -12 to -8 & $0-26 \%$ & $\begin{array}{c}\mathrm{C}_{3} \text {-forest to } \mathrm{C}_{3-} \\
\mathrm{C}_{4} \text { grass-forest } \\
\text { mosaic }\end{array}$ & Enamel isotopes & Martin et al. (2011) \\
\hline
\end{tabular}




\begin{tabular}{|c|c|c|c|c|c|c|}
\hline Inner Mongolia & $\begin{array}{l}25 \mathrm{Ma}- \\
\text { present }\end{array}$ & -13 to -2 & $0-80 \%$ & $\begin{array}{l}\mathrm{C}_{3} \text {-dominant to } \\
\mathrm{C}_{3}-\mathrm{C}_{4} \text { grass- } \\
\text { forest mosaic }\end{array}$ & Enamel isotopes & Zhang et al. (2009) \\
\hline $\begin{array}{l}\text { Myanmar } \\
\text { Africa }\end{array}$ & $6 \mathrm{Ma}$ & -14 to 2.6 & $\begin{array}{c}0- \\
100 \%\end{array}$ & $\begin{array}{l}\mathrm{C}_{3}-\mathrm{C}_{4} \text { grass- } \\
\text { forest mosaic }\end{array}$ & Enamel isotopes & $\begin{array}{l}\text { Zin-Maung-Maung-Thein et al. } \\
\qquad(2011)\end{array}$ \\
\hline \multirow[t]{2}{*}{ East Africa } & $\begin{array}{c}11.7-8.7 \\
\mathrm{Ma}\end{array}$ & -31.1 to -25.0 & $<20 \%$ & $\mathrm{C}_{3}$ grassland & Leaf wax isotopes & Feakins et al. (2013) \\
\hline & $5-1 \mathrm{Ma}$ & $\mathrm{n} / \mathrm{a}$ & - & $\begin{array}{l}\text { Grass-forest } \\
\text { mosaic }\end{array}$ & Pollen & Bonnefille (2010) \\
\hline Kenya & $10-4 \mathrm{Ma}$ & -10 to 2 & $\begin{array}{c}0- \\
100 \%\end{array}$ & $\begin{array}{l}\mathrm{C}_{3}-\mathrm{C}_{4} \text { grass- } \\
\text { forest mosaic }\end{array}$ & Enamel isotopes & Uno et al. (2011) \\
\hline Ethiopia & 4-3 Ma & -14 to 2 & $\begin{array}{l}50- \\
80 \%\end{array}$ & $\mathrm{C}_{3}-\mathrm{C}_{4}$ grassland & Enamel isotopes & Bedaso et al. (2013) \\
\hline South Africa & 14-3 Ma & -30 to -26 & $>10 \%$ & $\begin{array}{l}\mathrm{C}_{3}-\mathrm{C}_{4} \text { grass- } \\
\text { desert mosaic }\end{array}$ & $\begin{array}{l}\text { Pollen and leaf wax } \\
\text { isotopes }\end{array}$ & Dupont et al. (2013) \\
\hline \multicolumn{7}{|l|}{ Europe } \\
\hline Denmark & 19-8 Ma & $\mathrm{n} / \mathrm{a}$ & - & Forest-swamp & Pollen & Larsson et al. (2011) \\
\hline Spain & $35-15 \mathrm{Ma}$ & $\mathrm{n} / \mathrm{a}$ & $0-60 \%$ & $\begin{array}{l}\mathrm{C}_{3}-\mathrm{C}_{4} \text { grass- } \\
\text { forest mosaic }\end{array}$ & Pollen isotopes & Urban et al. (2010) \\
\hline
\end{tabular}

